\title{
Review
}

\section{Polymeric Dental Nanomaterials: Antimicrobial Action}

\author{
Pavel Yudaev ${ }^{1}$, Vladimir Chuev ${ }^{2}$, Bogdan Klyukin ${ }^{1}$, Andrey Kuskov ${ }^{1}$, , Yaroslav Mezhuev ${ }^{1}$ \\ and Evgeniy Chistyakov $1, *$ (i)
}

1 Mendeleev University of Chemical Technology of Russia, Miusskaya Sq., 9, 125047 Moscow, Russia; yudaevpavel5@gmail.com (P.Y.); bourne4432@gmail.com (B.K.); a_n_kuskov@mail.ru (A.K.); valsorja@mail.ru (Y.M.)

2 Belgorod National Research University, Pobedy Street, 85, 308015 Belgorod, Russia; mxpion@rambler.ru

* Correspondence: ewgenijj@rambler.ru

check for updates

Citation: Yudaev, P.; Chuev, V.; Klyukin, B.; Kuskov, A.; Mezhuev, Y.; Chistyakov, E. Polymeric Dental Nanomaterials: Antimicrobial Action. Polymers 2022, 14, 864. https:// doi.org/10.3390/polym14050864 Academic Editor: Andreea-Teodora Iacob

Received: 30 January 2022

Accepted: 19 February 2022

Published: 22 February 2022

Publisher's Note: MDPI stays neutral with regard to jurisdictional claims in published maps and institutional affiliations.

Copyright: (C) 2022 by the authors. Licensee MDPI, Basel, Switzerland. This article is an open access article distributed under the terms and conditions of the Creative Commons Attribution (CC BY) license (https:// creativecommons.org/licenses/by/ $4.0 /)$.

\begin{abstract}
This review aims to describe and critically analyze studies published over the past four years on the application of polymeric dental nanomaterials as antimicrobial materials in various fields of dentistry. Nanoparticles are promising antimicrobial additives to restoration materials. According to published data, composites based on silver nanoparticles, zinc(II), titanium(IV), magnesium(II), and copper(II) oxide nanoparticles, chitosan nanoparticles, calcium phosphate or fluoride nanoparticles, and nanodiamonds can be used in dental therapy and endodontics. Composites with nanoparticles of hydroxyapatite and bioactive glass proved to be of low efficiency for application in these fields. The materials applicable in orthodontics include nanodiamonds, silver nanoparticles, titanium(IV) and zinc(II) oxide nanoparticles, bioactive glass, and yttrium(III) fluoride nanoparticles. Composites of silver nanoparticles and zinc(II) oxide nanoparticles are used in periodontics, and nanodiamonds and silver, chitosan, and titanium(IV) oxide nanoparticles are employed in dental implantology and dental prosthetics. Composites based on titanium(IV) oxide can also be utilized in maxillofacial surgery to manufacture prostheses. Composites with copper(II) oxide nanoparticles and halloysite nanotubes are promising materials in the field of denture prosthetics. Composites with calcium(II) fluoride or phosphate nanoparticles can be used in therapeutic dentistry for tooth restoration.
\end{abstract}

Keywords: nanomaterials; dentistry; nanoparticles; antibacterial activity; antimicrobial action

\section{Introduction}

The terms nanoparticle, nanomaterial, and nanotechnology came into use in the second half of the 20th century and are identified by researchers with innovation and progress in science and industry. Currently, a high-priority area in global science is manufacturing of materials that contain particles comparable in size with molecules, which are called nanoparticles. They have found applications in medical imaging [1], biomedicine [2,3], pharmacology [4], photoelectronics [5] and optoelectronics [6,7], construction [8], photocatalysis [9], as components of heterogeneous catalysts [10,11], as a means of improving the mechanical [12] and thermal properties of polymeric materials [13], sensors [14] and biosensors [15], components of lithium-ion batteries [16], and sorbents [17].

A promising application area of composite nanomaterials is medicine, including dentistry, in which they are used for diagnosis, dental prosthetics, and prevention and treatment of diseases of the oral mucosa and hard tissues of teeth. These materials can reproduce mechanical, physicochemical, and esthetic properties of the hard tissues of teeth and often surpass them in strength characteristics. One more advantage of nanomaterials over traditional composites is that dental restoration can be made with good esthetic characteristics, identical to those of hard tooth tissues, as they possess better optical properties [18].

Decreasing the microbial action in oral cavity organs is an important issue in the prevention and treatment of caries and in restorative dentistry and dental prosthetics. Their large surface, very small size, and high surface energy and charge density allow 
nanoparticles to interact with the cell membrane, easily penetrate into a pathogen cell, and induce pathogen death [19].

Nanoparticles with a positive charge interact electrostatically with the negatively charged surface of the bacterial cell wall, disrupting the permeability of the cell membrane. In the first case, the respiratory chain of electron transport is blocked (* in Figure 1). In the second, the nanoparticle destroys the membrane, entering the cytoplasm of the bacterial cell, leading to the outflow of intracellular contents and death of the bacterial cell (** in Figure 1).

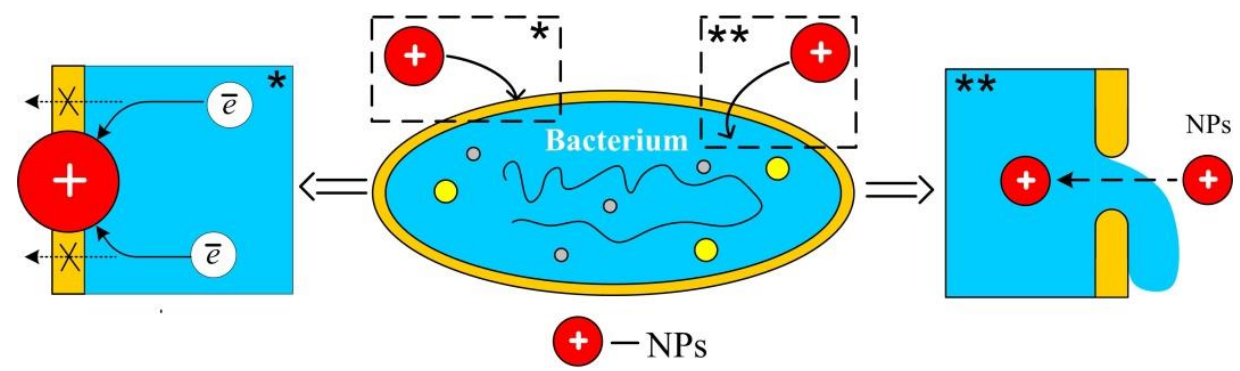

Figure 1. Mechanism of antimicrobial effect of positively charged nanoparticles (using the example of chitosan nanoparticles).

Previously, an extremely toxic amalgam was used as an antimicrobial dental material [20], which also has poor esthetic properties [21]. Since the 1970s, a less toxic glass ionomer cement (below referred to as GIC) with antimicrobial activity [22], but which has poor mechanical characteristics, has been used. The use of antibiotics leads to antibiotic resistance of microorganisms, as well as a large number of side effects on the part of the digestive system and the central nervous system [23], which limits their use in dentistry.

That is why, in the battle against pathogens, studies devoted to the development of various dental nanocomposites and devoid of most of the above disadvantages become extremely relevant and in demand. For example, studies [24,25] report that nanosized fillers of various classes impart reinforcing, antibacterial, remineralizing, self-curing, radiopaque, and esthetic properties to dental materials. Fauzi et al. [26] developed an esthetic adhesive composite material with antibacterial properties for use with esthetic orthodontic brackets.

Figure 2 shows the number of publications on polymeric dental nanomaterials with antimicrobial activity. The graph shows that most active development in this area was in 2012, 2013, 2019, and 2020. Until 2008, there were no publications on this topic.

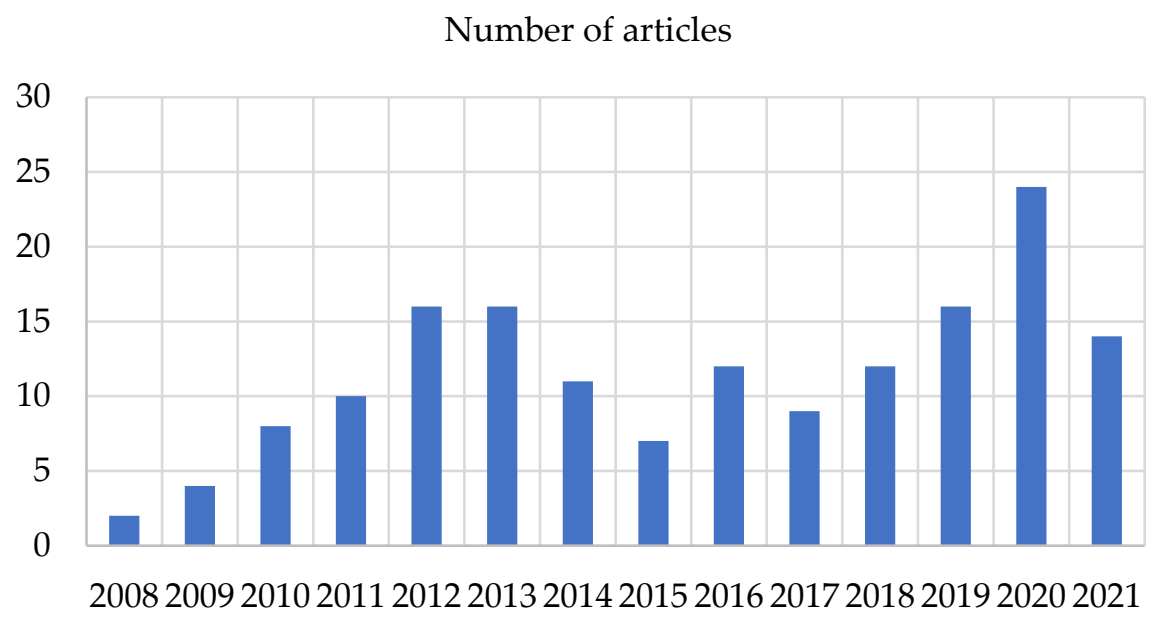

Figure 2. Number of articles on the antimicrobial activity of polymeric nanomaterials for dental applications (PubMed database). 
It should be mentioned that more than 100 reviews published in the period of 20182021 are devoted to the use of various types of nanoparticles in dentistry. These publications consider the use of nanoparticles in implantology [27,28], dental therapy [29,30], local drug delivery to treat periodontitis [31], in the treatment of oral cavity cancer [32], and in toothpastes [33]. However, the published reviews do not give detailed descriptions of the antibacterial or antifungal action of dental polymeric nanomaterials and prospects for their application in various fields of dentistry.

The present paper gives an overview of studies published in the period of 2018-2021 that address the antimicrobial properties of nanomaterials related to their use in dentistry. The information on nanoparticles used for dental materials is summarized in Table S1 in the Supplementary Materials.

\section{Nanoparticles with Antimicrobial Action Used in Dental Materials}

A variety of microorganisms are known in dentistry as pathogenic (Supplementary Materials, Table S2), and nanoparticles are active suppressors of many of them (Supplementary Materials, Table S3). Nanoparticles applicable as antimicrobial components include metal, oxide, diamond, glass, and polymeric nanoparticles.

Apart from their antimicrobial action, inorganic nanoparticles are able to improve the integrity of the hybrid layer at the resin-dentin interface [34,35], inhibit enamel demineralization [36] and formation of white spot lesions [37,38] during orthodontic treatment, increase the compressive strength $[39,40]$ and microhardness [41] of restorations based on glass ionomer cement, and reduce polymerization shrinkage of light-curing dental composites [42] and the surface roughness of dentures [43,44] and implants [45] (Supplementary Materials, Table S4).

The inorganic nanoparticles with antimicrobial action studied in recent years include silver, diamond, zinc(II) oxide, titanium(IV) oxide, zirconium(IV) oxide, magnesium(II) oxide, hydroxyapatite, glass, yttrium(III) fluoride, calcium(II) fluoride, and calcium(II) phosphate nanoparticles.

Biocompatible and biodegradable polymeric nanoparticles have shown a high therapeutic potential for controlled drug delivery techniques. The dosage forms based on polymeric nanoparticles penetrate deep into tissues, which increases the drug exposure time and efficiency and minimizes side effects.

Polymeric nanoparticles used in dentistry are subdivided into natural (chitosan, starch, sodium alginate) and synthetic ones (polylactide, poly(lactide-co-glycolide), polyethylene glycol-polylactide). Chitosan holds prospects for use in dentistry as an antimicrobial material.

Here we consider the general characteristics of nanoparticles that have antimicrobial action.

Silver nanoparticles (below referred to as Ag NPs) are spherically shaped biocompatible metal nanoparticles with a controllable size in the range from 3 to $35 \mathrm{~nm}$ [18].

Yaqoob et al. [46] discussed in detail chemical, physical, photochemical, and biological methods for the synthesis of silver nanoparticles. It is reported that the most simple, economical, and environmentally friendly method for the synthesis of silver nanoparticles is the biological or green method using plant extracts.

Ag NPs prepared by the reduction of silver nitrate with sodium borohydride or by green synthesis $[47,48]$ show a long-term activity against resistant microorganisms that cause caries, periodontitis, peri-implantitis, inflammation of root canals, and oral candidiasis. However, a tendency to aggregation increases the average size of Ag NPs, which may result in the loss of antibacterial properties. The stability of Ag NPs can be enhanced by using surfactants that contain polar groups and are capable of interacting with surface atoms [49], or by synthesizing Ag NPs in a polymeric matrix [50].

Nanodiamonds (below referred to as NDs) are nanocarbon materials characterized by high strength, hardness, optical transparency, low cytotoxicity, and better chemical stability and biocompatibility than metal or metal oxide nanoparticles. The hydroxy, amino, and carboxyl groups present on the NDs' surface improve their interfacial interactions with polymethyl methacrylate (below PMMA), polyethyl and polybutyl methacrylates, and 
urethane dimethacrylate resin. The antimicrobial effect of NDs is caused by negatively charged acid anhydride groups present on the surface [51].

Zinc(II) oxide nanoparticles (below referred to as $\mathrm{ZnO} N$ Ps), characterized by biocompatibility, low micro-density, and activity against S. mutans, E. faecalis, S. mitis, Lactobacillus spp., $P$. gingivalis, and A. naeslundii, have proved to be efficient in endodontic and orthodontic sealers, dental filling materials, and interim dental prostheses [34].

Titanium(IV) oxide nanoparticles (below referred to as $\mathrm{TiO}_{2} \mathrm{NPs}$ ) have spherical shape, a smooth surface, and uniform size distribution. $\mathrm{TiO}_{2} \mathrm{NPs}$ possess useful properties that make them suitable for preparation of dental filling materials, such as chemical stability, biocompatibility, tooth enamel-like color, and a hydrophilic surface. $\mathrm{TiO}_{2} \mathrm{NPs}$ with a particle size of less than $50 \mathrm{~nm}$ possess photoinduced activity and can release free radicals damaging the DNA of S. mutans and S. aureus bacteria [52].

Zirconium(IV) oxide nanoparticles (below referred to as $\mathrm{ZrO}_{2} \mathrm{NPs}$ ) are oval or spherical particles with a surface area of $9 \mathrm{~m}^{2} \mathrm{~g}^{-1}$ and an average size of $40 \mathrm{~nm}$.

$\mathrm{ZrO}_{2}$ NPs increase biaxial flexural strength and Vickers microhardness of GIC [41] and increase the tensile and compressive strength and chemical stability of PMMA [53].

Magnesium oxide(II) nanoparticles (below referred to as MgO NPs) possessing antibacterial activity are white hygroscopic particles with an average size of $20 \mathrm{~nm}$. MgO NPs are biocompatible, biodegradable, nontoxic, environmentally friendly, and cheaper than Ag NPs. However, like Ag NPs, they are prone to aggregation, which reduces the activity of nanoparticles against bacteria. Aggregation can be prevented by using cellulose, which provides a closer contact of nanoparticles with bacteria and thus bacterial growth can be inhibited by almost 100\% [54].

Hydoxyapatite nanoparticles (below referred to as nHAps) have a composition and structure similar to those of dental tissue, and, hence, they can be used to coat dentin caries lesions, microcracks in teeth, and dentinal tubules, and to enhance remineralization of demineralized dentin matrix and damaged enamel; this is important for dental therapy, implantology, tissue engineering, and treatment of hypersensitivity.

nHAps also stimulate proliferation, adhesion, and differentiation of mouse odontoblastlike MDPC-23 cells [55]; they enhance the biocompatibility of silver coatings of titanium implants with human primary osteoblasts [56].

Bioactive glass nanoparticles (below referred to as BGN) consist of silicon dioxide, calcium oxide, sodium oxide, and phosphorus $(\mathrm{V})$ oxide. In the oral cavity, this glass can release $\mathrm{Ca}^{2+}, \mathrm{PO}_{4}{ }^{3-}$, and $\mathrm{CO}_{3}{ }^{2-}$ ions, thus increasing $\mathrm{pH}$ of the medium and inactivating bacterial enzymes. They can also form hydroxycarbonate apatite (the product of crystallization of calcium phosphate on the glass surface), which takes part in the occlusion of dentinal tubules and enamel remineralization [57]. Bioactive glass nanoparticles have an irregular morphology and are prone to aggregation.

Yttrium(III) fluoride nanoparticles (below referred to as YFN) and calcium fluoride nanoparticles (below referred to as $\mathrm{nCaF}_{2}$ ) can affect the mineral layers of teeth, thus enhancing remineralization [58,59]. The average size of YFN is $60-70 \mathrm{~nm}$ [58], and the average size of $\mathrm{nCaF}_{2}$ is $32 \mathrm{~nm}[59]$.

Calcium phosphate nanoparticles (below referred to as NCP) are able to continuously release calcium ions and phosphate ions into the oral cavity, providing a remineralizing effect. They are amorphous calcium phosphate with a high surface area of $17.8 \mathrm{~m}^{2} \mathrm{~g}^{-1}$. Such systems are synthesized by spray drying, carried out by spraying an acetic acid solution of calcium carbonate and dicalcium phosphate into a heated chamber. Average particle size is $116 \mathrm{~nm}$ [60].

Copper (II) oxide nanoparticles (below referred to as $\mathrm{CuO}$ NPs) have an average size of $18 \mathrm{~nm}$. For the synthesis of copper oxide nanoparticles, ethanolic solutions of copper acetate and sodium hydroxide are used. They inhibit biofilm growth in soft denture liners in a dose-dependent manner [61].

Chitosan nanoparticles (below referred to as Cs NPs) are obtained by coagulation of the polymer from solutions of various concentrations in a treatment with acetic acid and 
cross-linking with sodium tripolyphosphate to form a polymer complex. The nanoparticles of chitosan-which is a biologically active, biocompatible, and biodegradable polymer-are used as carriers for targeted delivery of drugs such as doxycycline [62], amoxicillin and clavulanic acid [63], and simvastatin [64] to damaged dental tissue, which ensure prolonged drug release and thus decrease the therapeutic dose.

Halloysite nanotubes (below referred to as HNTs) are biocompatible aluminosilicate layers of a tubular structure with a diameter of several tens of nanometers and a length of approximately $200 \mathrm{~nm}$ [65].

\section{Dental Therapy, Endodontics, and Periodontics}

In dental therapy, nanomaterials are used as chemically curing, light-curing, and self-curing polymeric composites, glass-ionomer cements, insulating coatings, adhesives, and fissure sealants, while in endodontics such materials are used as root canal sealers.

\subsection{Materials Containing Silver Nanoparticles}

In dental therapy, composites with Ag NPs are used in dental restorative materials based on zirconia and GIC and used to treat carious lesions caused by S. mutans, S. salivarius, L. acidophilus, C. albicans, and C. glabrata.

A group of Polish researchers found that the addition of Ag NPs into the glass-ionomer cement Ketac Molar EasyMix, and adhesive systems Clearfil SE Bond and OptiBond Solo Plus, enhances the inhibition of growth of Gram-positive bacteria such as $S$. mutans, $S$. salivarius, and L. acidophilus after $48 \mathrm{~h}$ of observation [66].

Oh et al. [67] evaluated the activity against $S$. mutans of a filling material used for dental restoration based on zirconium dioxide coated by a glass-ceramic powder with addition of 5, 10, 15, and $20 \mathrm{wt}$ \% Ag NPs or NaF and found the following:

(1) The addition of $10 \mathrm{wt}$. \% and $20 \mathrm{wt}$. \% Ag NPs decreases bacterial activity by $11.8 \%$ and $15.4 \%$, respectively (Table 1 );

(2) The addition of 5-15 wt. \% NaF decreases the number of bacteria by $65 \%$, but when the NaF content increases to $20 \mathrm{wt}$. \%, the number of bacteria grows by $29 \%$ (Table 1 );

(3) Irrespective of Ag NPs and NaF content, the viability of L929 mouse fibroblast cells exceeds $70 \%$ for all samples, which attests to the safety of the composites.

Table 1. Bacterial reduction rate for S. mutans on the surface of $\mathrm{ZrO}_{2}$ disks coated by glass-ceramic powder containing Ag NPs and NaF after $24 \mathrm{~h}$ of observation.

\begin{tabular}{ccc}
\hline Composition & Content, wt. $\%$ & Bacterial Reduction Rate, \% \\
\hline Ag & 5 & 0 \\
& 10 & 0 \\
& 15 & 11.8 \\
$\mathrm{NaF}$ & 20 & 15.4 \\
\hline & 5 & 4.2 \\
& 10 & 35.3 \\
\end{tabular}

However, the authors gave no explanation for the higher rate of inhibition of the cells growth of $S$. mutans by NaF than by Ag NPs.

The mechanical endodontic treatment leaves significant areas of E. faecalis biofilm and necrotic tissues, which cause apical periodontitis. This problem can be solved by using Ag NP-based dual-cure adhesives, self-etch adhesive systems possessing long-term antibacterial action. Baras et al. [50] developed a dual-cure endodontic sealer based on dimethylamino hexadecyl methacrylate, a glass filler, and BTH resin (a mixture of bisphenol A glycidyl dimethacrylate, triethylene glycol dimethacrylate, 2-hydroxyethyl methacrylate, and methacryloyl oxyethyl phthalate) with addition of $0.15 \mathrm{wt}$. \% Ag NPs. As a result, 
the concentration of $E$. faecalis bacterial cells was reduced in comparison with commercial AH-Plus sealer from $10^{7.4}$ to $10^{4.7} \mathrm{CFU} \mathrm{mL}^{-1}$, thus preventing the secondary infection of the canals.

Modification of an acrylate self-etch adhesive system with an ethanol dispersion of Ag NPs resulted in increasing diameter of the inhibition zone of S. mutans on an agar plate from $11.6 \mathrm{~mm}$ to $13.8 \mathrm{~mm}$. However, upon addition of the Ag NPs' dispersion to an adhesive, the curing degree decreased from $50 \%$ to $26 \%$ since ethanol diluted the adhesive system [68].

The use of orthodontic retainers that control the position of front teeth after orthodontic treatment is often accompanied by an increasing area of bacterial biofilm. This elevates the risk of periodontal inflammation. To prevent biofilm growth, the addition of Ag NPs to lightcuring composite for orthodontic retainers was proposed [69]. A comparison of the activities of composites with Ag NPs (1 wt. \%) and without Ag NPs against T. denticola showed bacterial viability two orders of magnitude lower for Ag NP-containing samples than for samples without nanoparticles $\left(6 \cdot 10^{4} \mathrm{CFU} \mu \mathrm{L}^{-1}\right.$ and $3 \cdot 10^{6} \mathrm{CFU} \mu \mathrm{L}^{-1}$, respectively).

It is known that periodontal dressing should protect the wound surface after periodontal surgery and facilitate fast healing of the wound tissue. Therefore, Ag NPs were added to increase the efficiency of the polyvinyl alcohol-based dressing, and characteristics of post-surgery periodontal inflammation in rats were estimated using the ${ }^{99 \mathrm{~m}} \mathrm{Tc}$-ciprofloxacin radiopharmaceutical. Despite the fact that the content of the ${ }^{99 \mathrm{~m}}$ Tc-ciprofloxacin marker at the site of dressing with Ag NPs increased after 2 days due to the body's response to the foreign material, after 4 days the proportion of inflammation decreased [70].

Thus, Ag NPs are promising additives to polymeric materials used in dentistry for periodontics. This is due, first of all, to their anti-inflammatory and wound-healing activity. In addition, silver nanoparticles stabilized by biopolymers have high biocompatibility with human gingival fibroblasts [71].

\subsection{Materials Containing Zinc Oxide Nanoparticles}

$\mathrm{ZnO}$ NPs proved to be efficient against anaerobic Gram-positive S. mutans, S. mitis, and Lactobacillus spp. strains under microaerophilic conditions, which mimic a carious cavity [72]. As shown in Figure 3, minimum inhibitory concentration (MIC) values for $\mathrm{ZnO}$ NPs were $1.2 \mathrm{mg} \mathrm{mL}^{-1}$ for $S$. mitis and $0.6 \mathrm{mg} \mathrm{mL}^{-1}$ for $S$. mutans and Lactobacillus spp. In addition, a slight bactericidal effect was observed at a concentration of only $0.2 \mathrm{mg} \mathrm{mL}^{-1}$. The obtained material was meant for the use in resin filler materials.

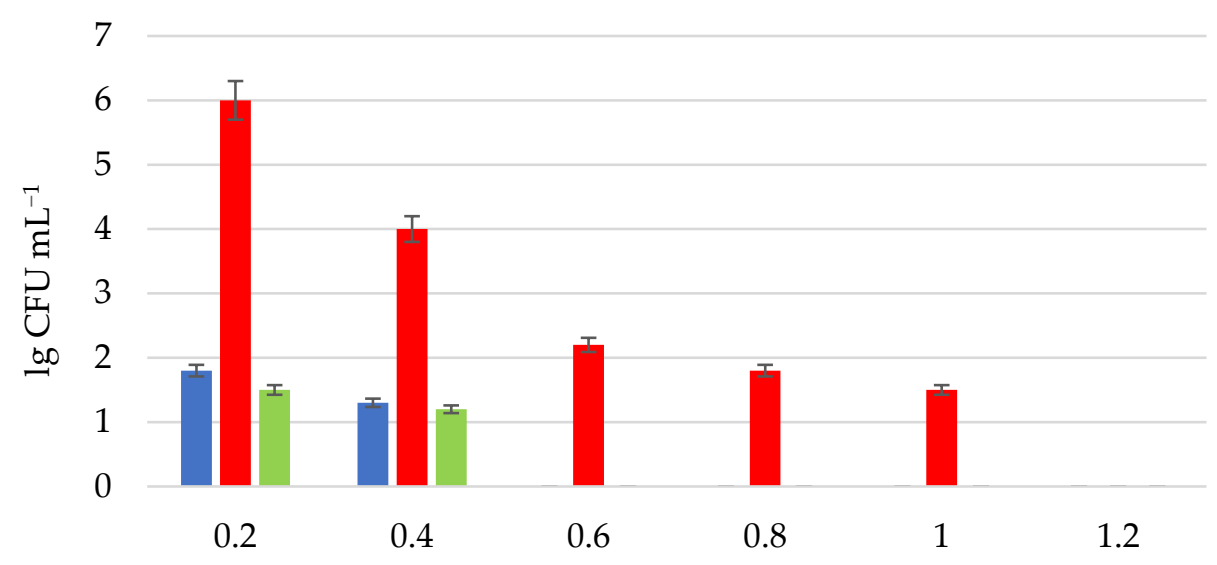

Concentration of $\mathrm{ZnO} \mathrm{NPs}, \mathrm{mg} \mathrm{mL}^{-1}$
S. mutans
S. mitis
Lactobacillus spp.

Figure 3. Effects of ZnO NPs (lg CFU $\mathrm{mL}^{-1}$ ) on the growth of S. mutans (blue), S. mitis (red), and Lactobacillus spp. (green) in the thioglycolate broth after $18 \mathrm{~h}$ at $37^{\circ} \mathrm{C}$ under microaerophilic conditions [72]. 
Angel Villegas et al. [72] also found that ZnO NPs in Icon methacrylate resin penetrate to a depth of up to $1020 \mu \mathrm{m}$ from the tooth surface, which indicates a good infiltration ability of the nanomaterial.

The antimicrobial effect of ZnO NPs allowing for overcoming antibiotic resistance of $S$. mutans, E. faecalis, L. fermentum, and C. albicans was detected by the disk diffusion test and microdilution method [73]. In control groups, the antibiotics gentamicin and ampicillin were used for the abovementioned bacteria and fluconazole was used for the C. albicans fungus. The results showed an increase in the antimicrobial activity as the particle size decreased from $140 \mathrm{~nm}$ to $20 \mathrm{~nm}$. The greatest inhibition zones against $S$. mutans were observed for $20 \mathrm{~nm}$ and $40 \mathrm{~nm}$ ZnO NPs, whereas $140 \mathrm{~nm}$ ZnO NPs formed the greatest inhibition zones against $S$. mutans and E. faecalis. The inhibition zones of $C$. albicans were the smallest for all three sizes of ZnO NPs (Table 2). In this regard, based on the data, nanoparticles were used in root canal polymer sealers. It was found that the diameters of inhibition zones against $P$. gingivalis and $A$. naeslundii were greater for $\mathrm{ZnO}$ NPs (18.09 mm and $12.05 \mathrm{~mm}$ ) than for commercial light-curing AH Plus A sealer (9 mm) [74].

Table 2. Diameters of zones of growth inhibition of microorganisms, $\mathrm{mm}$.

\begin{tabular}{ccccc}
\hline Microorganism & $\mathbf{2 0} \mathbf{~ n m ~ Z n O ~ N P s ~}$ & $\mathbf{4 0} \mathbf{~ n m ~ Z n O ~ N P s}$ & $\mathbf{1 4 0} \mathbf{~ n m ~ Z n O ~ N P s}$ & Control \\
\hline S. mutans & $16 \pm 0.00$ & $14 \pm 0.00$ & $12.03 \pm 0.57$ & $21 \pm 0.00$ \\
\hline E. faecalis & $14.33 \pm 0.57$ & $13 \pm 0.00$ & $12 \pm 1.00$ & $26 \pm 0.00$ \\
\hline L. fermentum & $10 \pm 0.00$ & $9.33 \pm 0.57$ & $8.33 \pm 0.57$ & $23 \pm 0.00$ \\
\hline C. albicans & $7.66 \pm 2.08$ & $6 \pm 0.00$ & $6 \pm 0.00$ & $16 \pm 0.00$ \\
\hline
\end{tabular}

The antimicrobial activity of nanoparticles based on ZnO NPs and ZnO NPs encapsulated in chitosan against microorganisms B. subtilis, S. aureus, S. hemoliticus, P. aeruginosa, $K$. pneumoniae, E. coli was studied (Table 3). S. mutans and L. acidophilus biofilm inhibition was tested using 3M ESPE Adper ${ }^{\mathrm{TM}}$ Single Bond Adhesive dental adhesive disks containing nanoparticles [75].

Table 3. Antibacterial activity exhibited by ZnO NPs, chitosan ZnO NPs against Gram-positive and Gram-negative bacterial strains.

\begin{tabular}{ccc}
\hline Nanoparticles & Microorganism & Zone of Inhibition \\
\hline \multirow{3}{*}{ ZnO NPs } & B. subtillis & $7 \pm 3$ \\
& S. aureus & $8 \pm 3$ \\
& S. heamoliticus & $9 \pm 3$ \\
& P. aeroginosa & $9 \pm 3$ \\
K. pneumoniae & $10 \pm 3$ \\
E. coli & $10 \pm 3$ \\
\hline \multirow{2}{*}{ Chitosan ZnO NPs } & B. subtillis & $9 \pm 3$ \\
& S. aureus & $10 \pm 3$ \\
& S. heamoliticus & $12 \pm 3$ \\
& P. aeroginosa & $10 \pm 3$ \\
& K. pneumoniae & $13 \pm 3$ \\
& E. coli & $12 \pm 3$ \\
\hline
\end{tabular}

It should be mentioned that $\mathrm{ZnO}$ NPs with chitosan showed stronger antimicrobial activity than without the polymer. According to the authors, this is due to the synergy of the bactericidal activity of ZnO NPs and chitosan.

As for composites based on modified adhesives, the authors [75] describe their anticaries effect from two positions: (1) preventing the development of recurrent caries on teeth previously treated for it by affecting the structural elements of dentin; (2) reduction in the number of cariogenic bacteria such as $S$. mutans and L. acidophilus. 
According to the results obtained (Table 4), adhesives containing ZnO NPs and chitosan $\mathrm{ZnO}$ NPs reduced the number of cariogenic bacteria S. mutans and L. acidophilus by four orders in comparison to the control group (adhesive without nanoparticles).

Table 4. Anti-cariogenic activity of adhesive disks containing different concentrations of ZnO NPs and chitosan ZnO NPs.

\begin{tabular}{|c|c|c|c|}
\hline Nanoparticles & Concentration of NPs, wt. $\%$ & Days & Mean CFU mL $\mathrm{m}^{-1}$ \\
\hline \multirow{12}{*}{$\mathrm{ZnO}$ NPs } & \multirow{3}{*}{0 (control) } & 1 & $2.05 \times 10^{5}$ \\
\hline & & 3 & $3.26 \times 10^{5}$ \\
\hline & & 7 & $3.17 \times 10^{5}$ \\
\hline & \multirow{3}{*}{2} & 1 & $5.44 \times 10^{1}$ \\
\hline & & 3 & $4.91 \times 10^{1}$ \\
\hline & & 7 & $3.81 \times 10^{1}$ \\
\hline & \multirow{3}{*}{5} & 1 & $5.25 \times 10^{1}$ \\
\hline & & 3 & $3.88 \times 10^{1}$ \\
\hline & & 7 & $2.87 \times 10^{1}$ \\
\hline & \multirow{3}{*}{10} & 1 & $3.61 \times 10^{1}$ \\
\hline & & 3 & $3.26 \times 10^{1}$ \\
\hline & & 7 & $3.28 \times 10^{1}$ \\
\hline \multirow{9}{*}{ Chitosan ZnO NPs } & \multirow{3}{*}{2} & 1 & $2.42 \times 10^{1}$ \\
\hline & & 3 & $1.85 \times 10^{1}$ \\
\hline & & 7 & $3.19 \times 10^{1}$ \\
\hline & \multirow{3}{*}{5} & 1 & $2.54 \times 10^{1}$ \\
\hline & & 3 & $1.41 \times 10^{1}$ \\
\hline & & 7 & $2.84 \times 10^{1}$ \\
\hline & \multirow{3}{*}{10} & 1 & $1.46 \times 10^{1}$ \\
\hline & & 3 & $1.16 \times 10^{1}$ \\
\hline & & 7 & $1.77 \times 10^{1}$ \\
\hline
\end{tabular}

However, the contribution of L. acidophilus to the pathogenesis of carious disease is ambiguous, which is explained by their antagonistic effect on true cariogenic strains of microorganisms (S. mutans, S. sanguinis, S. salivarius) on the one hand, and the production of 2-hydroxypropanoic acid, which has a demineralizing effect on inorganic part of enamel and dentin, on the other hand.

\subsection{Materials Containing Titanium(IV) Oxide Nanoparticles}

A comparison of the antibacterial activity of GICs containing antibiotics and $\mathrm{TiO}_{2}$ NPs [40] showed that the inhibition zone of $\mathrm{TiO}_{2}$ NPs containing GIC against $S$. mutans was $21.2 \mathrm{~mm}$, that of cetylpyridinium chloride-containing sample was $18.3 \mathrm{~mm}$, and that of ampicillin-containing sample was $31.2 \mathrm{~mm}$. Meanwhile, ampicillin particles deteriorate the interaction between glass particles and liquid cement and, hence, decrease the compressive strength of GIC. Conversely, $\mathrm{TiO}_{2}$ NPs fill the voids between glass particles and thus increase the compressive strength of GIC from $140 \mathrm{MPa}$ to $173 \mathrm{MPa}$.

The antibacterial activity against $S$. mutans [76] was also evaluated for an acrylic dental composite resin, Filtek Z350 XT, filled with $\mathrm{TiO}_{2}$ NPs. The direct contact assay showed that increase in the content of nanoparticles results in decreasing bacterial growth. The incorporation of $2 \% \mathrm{TiO}_{2} \mathrm{NPs}$ into the resin reduced the bacterial concentration in the culture broth (BHI + 1\% saccharose) by $75 \%$ without deterioration of mechanical or physicochemical properties.

Thus, $\mathrm{TiO}_{2}$ NPs can be used as antibacterial fillers for materials meant for tooth restoration.

Florez et al. [52] investigated the OptiBond Solo Plus dental acrylic adhesives containing $\mathrm{TiO}_{2}$ NPs for activity against $S$. mutans biofilms. Determination of viable bacterial counts using bioluminescence assay showed that the antibacterial properties of the samples 
increase with increasing content of $\mathrm{TiO}_{2}$ NPs, irrespective of the time of bacterial growth ( 3 to $24 \mathrm{~h}$ ). The authors also showed that nitrogen-doped $\mathrm{TiO}_{2} \mathrm{NPs}$ are photoactive and their antibacterial properties increase upon long-term $(24 \mathrm{~h})$ irradiation with light. However, it is unclear how long-term irradiation of this adhesive can be carried out in an oral cavity.

\subsection{Materials Containing Magnesium(II) Oxide Nanoparticles}

In a study of the action of GIC modified by MgO NPs on S. mutans and S. sobrinus, the agar diffusion test demonstrated that GICs containing up to $1 \mathrm{wt}$ \% MgO NPs do not suppress bacterial growth $[77,78]$. As the concentration of $\mathrm{MgO}$ NPs increases, the diameter of inhibition zones increases and reaches $9 \mathrm{~mm}$ for $10 \mathrm{wt}$. \% MgO NPs.

The biocompatibility of MgO NPs makes them perfect candidates for clinical use in dentistry as parts of polymeric filling and restoration materials. However, as indicated above, the antibacterial activity is manifested only when the nanoparticle content in the composites is higher than $1 \mathrm{wt}$ \%.

\subsection{Materials Containing Hydroxyapatite Nanoparticles}

The introduction of nHAps in an amount of $10 \mathrm{wt}$. \% to $30 \mathrm{wt}$ \% in acrylic binder based on bisphenol A glycidyl dimethacrylate and triethylene glycol dimethacrylate promotes remineralization of enamel affected by S. mutans biofilm [79]. For 98 days of observation, it was found that with an increase in the concentration of nanoparticles in the composite, the released amount of calcium ions and phosphate ions also increased. It is also reported that at potentially cariogenic $\mathrm{pH}=4$, more calcium and phosphate ions are released than at $\mathrm{pH}=7$ (oral $\mathrm{pH})$.

However, it should be noted that with an increase in the content of nHAps in composites, their bending strength decreased. The authors explain this fact by the poor interaction between the organic matrix and mineral nHAps. A statistically significant decrease in the translucency of the composites was also observed with an increase in the content of nHAps from $20 \mathrm{wt}$. \% to $30 \mathrm{wt}$. \%. Unfortunately, the authors do not provide an explanation for this fact.

\subsection{Materials Containing Bioactive Glass Nanoparticles}

Al-Bakhash et al. [80] estimated the activity of an epoxy resin-based dental sealer, Dentsply Maillefer, modified by various nanofillers: hydoxyapatite, fluorohydroxyapatite, and BGN against Gram-positive E. faecalis and S. mitis bacteria. The most pronounced antimicrobial properties were observed for sealers doped with fluorohydroxyapatite nanoparticles, since Gram-positive bacteria with negatively charged peptidoglycans are more susceptible to hydroxyapatite than to bioactive glass (CFU mL $\mathrm{mL}^{-1}$ of E. faecalis and S. mitis decreased by $15 \%$ and $17 \%$, while in the case of BGN, the decrease was only $2 \%$ and $4 \%$ ). Thus, bioactive glass is barely useful for dental therapy.

\subsection{Materials Containing Chitosan Nanoparticles}

A comparison of the antibacterial properties against $S$. mutans for three composites based on Cs NPs (83 nm size), Cs NPs/ZnO NPs (186 nm size), and ZnO NPs (38 nm size) demonstrated that the introduction of ZnO NPs into the acrylic composite resin Filtek Z250 Universal Restorative provides an antibacterial effect, which is retained for up to 12 weeks, while for chitosan-containing composites it is retained only for 2 weeks. The inhibition zone was also larger for microhybrid composites containing $\mathrm{ZnO}$ NPs than for composites based on Cs NPs (Table 5). This may be due to the smaller size and low tendency for aggregation inherent in zinc oxide nanoparticles and, hence, to their greater surface publications. 
Table 5. Width of the inhibition zone against $S$. mutans, $\mathrm{mm}$.

\begin{tabular}{ccccc}
\hline Sample & $\mathbf{2 4} \mathbf{~ h}$ & $\mathbf{2 ~ W e e k s}$ & $\mathbf{6}$ Weeks & $\mathbf{1 2}$ Weeks \\
\hline $\begin{array}{c}\text { Filtek Z250 microhybrid } \\
\text { composite resin }\end{array}$ & $6.0 \pm 0.0$ & $6.0 \pm 0.0$ & $6.0 \pm 0.0$ & $6.0 \pm 0.0$ \\
\hline Resin + ZnO NPs & $18.0 \pm 0.71$ & $16.0 \pm 1.58$ & $14.0 \pm 0.71$ & $8.0 \pm 0.71$ \\
\hline Resin + Cs NPs & $18.0 \pm 1.87$ & $10.0 \pm 1.0$ & $6.0 \pm 0.0$ & $6.0 \pm 0.0$ \\
\hline Resin + Cs NPs/ZnO NPs & $15.80 \pm 1.48$ & $10.0 \pm 0.71$ & $6.0 \pm 0.0$ & $6.0 \pm 0.0$ \\
\hline$p$ & $<0.001^{*}$ & $<0.001^{*}$ & $<0.001^{*}$ & $<0.001^{*}$ \\
\hline
\end{tabular}

* Statistically significant at $p \leq 0.05$.

Thus, according to published data, polymeric materials filled with Ag NPs and $\mathrm{TiO}_{2}$ NPs are most promising for the use in dental therapy and endodontics, first of all, for the treatment of primary and secondary caries lesions. This is due to the fact that silver nanoparticles and titanium(IV) oxide nanoparticles can simultaneously improve the antimicrobial and mechanical properties of dental material. $\mathrm{Ag} \mathrm{NPs}$ and $\mathrm{TiO}_{2} \mathrm{NPs}$ occupy voids in the GIC, acting as additional contact points between the binder and glass particles. This increases the compressive strength $[39,81]$, flexural strength, and Vickers microhardness of the composites and the micro-shear bond strength to dentin [82].

\subsection{Materials Containing Calcium Phosphate Orcalcium Fluoride Nanoparticles}

Most modern composite dental materials are formed in the process of photopolymerization of low molecular weight binders. In this regard, there is a problem of shrinkage, which often leads to damage to fillings and restorations in the form of microcracks, which contributes to their colonization by microorganisms. A study was conducted aimed at reducing the shrinkage of composites [83]. The composite included urethane dimethacrylate, thriethylene glycol divinylbenzyl ether, and dimethylaminohexadecyl methacrylate. NCP (20 wt. \%) and silanized barium boroaluminosilicate glass particles (43 wt. \%) were used as fillers.

The resulting material had a $40 \%$ lower polymerization stress compared to the commercial Heliomolar composite (Ivoclar, Ontario, Canada). In addition, the developed composite material protected tooth enamel from demineralization caused by $S$. mutans biofilm by $5.17 \pm 0.48 \mathrm{mmol} \mathrm{L}^{-1}$. The cytotoxicity of the composite material in relation to the human gingival fibroblast cell was similar to that of the composite based on bisphenol A glycidyl dimethacrylate, which indicated that the developed material is suitable for clinical use.

Also of interest are composite materials containing fluoride anions that release them into the environment surrounding the material. The authors of [59] fabricated a composite based on acrylic resin containing $15 \mathrm{wt} . \% \mathrm{nCaF}_{2}$ as filler and $3 \mathrm{wt}$. \% dimethylaminohexadecyl methacrylate. The CFU values of biofilm grown on composite disks decreased by four orders of magnitude compared to the commercial composite Heliomolar (Ivoclar Vivadent, Mississauga, ON, Canada). The release of fluoride ions after 70 days of observation was $0.20 \pm 0.03 \mathrm{mmol} \mathrm{L}^{-1}$, calcium ions $0.18 \pm 0.005 \mathrm{mmol} \mathrm{L}^{-1}$, while for the commercial composite the release of calcium and fluoride ions was close to zero. The developed material also significantly (by $60 \%$ ) reduced the production of lactic acid by bacteria compared to the commercial composite.

However, the authors of works $[59,83]$ did not take into account the remineralizing effect of saliva and used only one type of bacteria, S. mutans.

Summarizing, we can conclude that materials filled with zinc oxide and chitosan nanoparticles, as well as nanoparticles of calcium phosphate and fluoride, are highly active against the main caries bacteria (S. mutans). Zinc oxide nanoparticles are also active against bacteria causing periodontitis and apical periodontitis (P. gingivalis, A. naeslundii) and can be used as additives to fillers and sealers for filling root canals and for treatment of periodontitis. 
Restorative materials filled with magnesium oxide, bioactive glass, and hydroxyapatite nanoparticles have low efficacy against pathogens and are fluoride inapplicable as antimicrobial additives.

\section{Orthodontics}

In orthodontics, nanoparticles are added to orthodontic adhesives and acrylic resins and are used as coatings for orthodontic appliances, in particular, orthodontic brackets.

Orthodontic appliances such as metallic and esthetic braces, rings, arcs, and bands complicate oral hygiene and create favorable conditions for the growth of $S$. mutans, $S$. aureus, S. sobrinus, S. sanguis, P. gingivalis, E. coli, and L. acidophilus biofilms, which increases the risk of tooth surface lesions.

In the field of orthodontics, most prospective are materials containing silver, titanium(IV) oxide, zinc(II) oxide, bioactive glass, and yttrium(III) fluoride nanoparticles and nanodiamonds.

\subsection{Materials Containing Silver Nanoparticles}

Orthodontic adhesives containing Ag NPs decrease bacterial adhesion at the brace/ enamel interface.

The adhesive composite materials meant for attachment of orthodontic brackets should also possess antimicrobial action in order to prevent the formation of white spots. Lee et al. [84] tested an antimicrobial resin based on the Transbond XT primer with the addition of Ag NPs. The antibacterial activity of this resin was evaluated in vitro against two oral pathogens, S. mutans and S. sobrinus. In both cases, the percentages of viable bacterial cells considerably decreased.

A comparison of the antibacterial activities of this resin against S. mutans and $L$. acidophilus indicated that the diameter of the inhibition zones against $S$. mutans growth was greater than that against L. acidophilus growth [85].

The authors of [86] studied the antimicrobial effect of composite resin disks based on acrylic composite resin Flow Tain (Reliance, Houston, TX, USA), containing 1 wt. \%, 2 wt. \%, and 5 wt. \% Ag NPs, against the bacteria S. mutans, S. sanguis, and L. acidophilus. The results obtained are presented in Table 6.

Table 6. Results of biofilm inhibition tests for S. mutans, S. sanguis, and L. acidophilus for composite disks containing Ag NPs and control group.

\begin{tabular}{cccc}
\hline Sample & Microorganism & CFU & $\begin{array}{c}\text { CFU mL } \mathbf{m L}^{-\mathbf{1}} \text { Decrease (\%) } \\
\text { Compared to the Control Group }\end{array}$ \\
\hline \multirow{2}{*}{ Control } & S. mutans & $56,666 \pm 30,550$ & - \\
& S. sanguis & $446,666 \pm 117,189$ & - \\
& L. acidophilus & $146,666 \pm 32,145$ & - \\
\hline Composite disks containing & S. mutans & $7000 \pm 1000$ & 87.64 \\
1 wt. \% Ag NPs & S. sanguis & $8333 \pm 1527$ & 98.13 \\
& L. acidophilus & $27,000 \pm 7549$ & 81.59 \\
Composite disks containing & S. mutans & $2000 \pm 1000$ & 96.47 \\
2 wt. \% Ag NPs & S. sanguis & $2333 \pm 1527$ & 99.47 \\
\hline \multirow{2}{*}{ Composite disks containing } & L. acidophilus & $13,333 \pm 2516$ & 90.9 \\
5 wt. \% Ag NPs & S. mutans & $133 \pm 57$ & 99.76 \\
\hline
\end{tabular}

According to the data obtained, composites containing AgNPs reduce the number of colonies of microorganisms in a dose-dependent manner. The largest decrease in CFU was observed for the biofilm of oral bacteria S. sanguis compared to S. mutans and L. acidophilus. 
However, the zone of inhibition was observed only for composites with the highest content of nanoparticles, equal to $5 \mathrm{wt}$. \%. The authors do not provide an explanation for this fact.

The resulting composites, according to the authors, after clinical trials can be used in orthodontics as orthodontic appliances.

\subsection{Materials Containing Titanium(IV) Oxide Nanoparticles}

In a comparison of antibacterial activities against $S$. mutans in three groups of Transbond XT acrylate composites modified with Ag NPs, $\mathrm{ZnO}$ NPs, and $\mathrm{TiO}_{2} \mathrm{NPs}$, the viable bacterial count decreased in all cases. Nevertheless, the antibacterial activity was higher for the $\mathrm{TiO}_{2}$ NP-containing group than for the Ag NPs and ZnO NP-containing groups, which is due to smaller size of $\mathrm{TiO}_{2}$ NPs $(25 \mathrm{~nm})$ compared with Ag NPs $(80 \mathrm{~nm})$ and $\mathrm{ZnO}$ NPs (50 nm) [87].

The antibacterial properties of composite disks based on a thriethylene glycol dimethacrylate, diurethane dimethacrylate resin mixture (50:50 wt./wt.) and nitrogen-doped $\mathrm{TiO}_{2}$ NPs were studied in relation to cariogenic bacteria $S$. mutans [26]. The nanoparticles were doped with nitrogen to prevent discoloration of the resin composite containing the nanoparticles after exposure to visible light. The antibacterial effect was assessed by the metabolic activity of bacterial cells under illumination conditions (indicator-tetrazolium salt). A decrease in absorption was observed with the addition of $\mathrm{TiO}_{2} \mathrm{NPs}$, and with increasing concentration of nanoparticles, the decrease in absorption increased (Table 7). As can be seen from Table 7, the surface treatment of the composite with both polishing and plasma contributed to the improvement in antibacterial action compared to untreated composites.

Table 7. The mean absorbance observed for resin disk samples with different wt. \% powder concentrations (0-9 wt. \%), exposed to different surface treatments (unpolished, plasma treated, polished, and polished with plasma treatment) under light conditions.

\begin{tabular}{|c|c|c|}
\hline Surface Treatment & $\begin{array}{l}\text { Concentration of Nitrogen- } \\
\text { Doped } \mathrm{TiO}_{2} \text { NPs, wt. } \%\end{array}$ & Absorbance (a.u.) \\
\hline \multirow{6}{*}{ Untreated } & 0 & $0.072 \pm 0.002$ \\
\hline & 1 & $0.069 \pm 0.005$ \\
\hline & 3 & $0.066 \pm 0.002$ \\
\hline & 5 & $0.060 \pm 0.004$ \\
\hline & 7 & $0.058 \pm 0.004$ \\
\hline & 9 & $0.056 \pm 0.004$ \\
\hline \multirow{6}{*}{ Plasma treated } & 0 & $0.072 \pm 0.002$ \\
\hline & 1 & $0.067 \pm 0.004$ \\
\hline & 3 & $0.066 \pm 0.005$ \\
\hline & 5 & $0.060 \pm 0.004$ \\
\hline & 7 & $0.056 \pm 0.004$ \\
\hline & 9 & $0.055 \pm 0.004$ \\
\hline \multirow{6}{*}{ Polished treated } & 0 & $0.072 \pm 0.001$ \\
\hline & 1 & $0.067 \pm 0.005$ \\
\hline & 3 & $0.056 \pm 0.004$ \\
\hline & 5 & $0.055 \pm 0.004$ \\
\hline & 7 & $0.052 \pm 0.004$ \\
\hline & 9 & $0.049 \pm 0.004$ \\
\hline \multirow{6}{*}{ Polished with plasma treated } & 0 & $0.072 \pm 0.001$ \\
\hline & 1 & $0.066 \pm 0.004$ \\
\hline & 3 & $0.052 \pm 0.004$ \\
\hline & 5 & $0.047 \pm 0.004$ \\
\hline & 7 & $0.044 \pm 0.004$ \\
\hline & 9 & $0.041 \pm 0.004$ \\
\hline
\end{tabular}


In the future, the authors plan to investigate the effect of other microorganisms on the inhibitory effect of $\mathrm{TiO}_{2}$ NPs doped with nitrogen.

\subsection{Materials Containing Nanodiamond}

It was shown by Mangal et al. [88] that composites based on Ortho-Jet orthodontic acrylic resin meant for the manufacture and repair of orthodontic appliances, containing $0.1,0.3$, and 0.5 wt. \% of ND powder, are active against $C$. albicans fungi. The CFU count decreased almost to zero upon the addition of only $0.1 \mathrm{wt} \%$ NDs to the resin. The biofilm thickness and weight decreased for all concentrations of NDs. However, further studies are required to establish the mechanism of interaction of composites with the microbes. It is also noteworthy that the addition of NDs deteriorated the optical properties of the composite.

In work [89], the antibacterial and tribological properties of a composite based on PMMA containing $0.1 \mathrm{wt}$. \% ND powder were studied by Mangal et al. For this, samples were obtained by 3D printing and studied in vitro. A polymer without nanoparticles served as control sample.

The severity of the antibacterial effect of the composite was assessed by the resistance to the formation of biofilms based on $S$. mutans on these materials for $48 \mathrm{~h}$. It was found that the biofilm thickness decreased from $200 \mu \mathrm{m}$ (control group) to $150 \mu \mathrm{m}$ (nanocomposite), while biofilm biomass decreased from $120 \mu^{3} \mu^{-2}$ (control group) to $30 \mu \mathrm{m}^{3} \mu \mathrm{m}^{-2}$ (composite).

In addition, composite increased Vickers microhardness and wear resistance, as well as reduced the coefficient of friction, compared with the control group. The pronounced antibacterial effect and good performance characteristics of diamond composites allow them to be recommended for use in orthodontics for the manufacture of orthodontic appliances.

\subsection{Materials Containing Zinc(II) Oxide Nanocomposites}

Pourhajibagher et al. [90] evaluated the antimicrobial properties against S. mutans, S. sobrinus, and L. acidophilus for the Transbond XT acrylic orthodontic adhesive containing cationic curcumin-doped ZnO NPs. The results, summarized in Table 8, indicate than the samples retained antimicrobial properties after 180 days of observation.

Table 8. Sizes of the inhibition zones of bacterial growth by orthodontic adhesives containing photoactivated 7.5 wt. \% ZnO NPs/cCur, mm

\begin{tabular}{lcccccccc}
\hline \multirow{2}{*}{ Microorganisms } & \multicolumn{9}{c}{ Days } \\
\cline { 2 - 9 } & $\mathbf{1}$ & $\mathbf{1 5}$ & $\mathbf{3 0}$ & $\mathbf{6 0}$ & $\mathbf{9 0}$ & $\mathbf{1 2 0}$ & $\mathbf{1 5 0}$ & $\mathbf{1 8 0}$ \\
\hline S. mutans & 13 & 13 & 13 & 11 & 7 & 7 & 6 & 6 \\
S. sobrinus & 13 & 12 & 12 & 11 & 7 & 7 & 6 & 5 \\
L. acidophilus & 10 & 10 & 10 & 5 & 5 & 5 & 5 \\
\hline
\end{tabular}

\subsection{Materials Containing Bioactive Glass Nanoparticles}

Nam et al. [36] modified the low-viscosity acrylic orthodontic bonding resin Transbond Supreme LV with BGN particles. Samples with 3 wt. \% and 5 wt. \% BGN were evaluated for the antibacterial activity against Gram-positive $S$. mutans bacteria.

For both concentrations of nanoparticles, the antibacterial activity against $S$. mutans after $48 \mathrm{~h}$ of culturing of BGN samples in the BHI broth was higher than that for unfilled bonding resin.

\subsection{Materials Containing Yttrium(III) Fluoride Nanoparticles}

Yttrium(III) fluoride nanoparticles can also be used in orthodontics as a component of orthodontic polymeric adhesive. Asiry et al. [58] evaluated the adhesive strength and antibacterial effect of Transbond XT acrylic orthodontic composite resins mixed with yttrium fluoride nanoparticles, with an average particle size of $60-70 \mathrm{~nm}$. The presence of YFN in the resin in concentration of $1 \mathrm{wt}$. \% induced a considerable antibacterial effect 
against $S$. mutans, as indicated by CFU decrease from 75.85 to 2.24 . There was no statistically significant decrease in the bracket-enamel adhesive strength (11.61 $\mathrm{MPa}$ in the control group and 11.44 MPa in the test group). The antibacterial action of YFN was attributed [57] to the formation of metal fluoride complexes with bacterial peroxidases. It is noteworthy that an increase in the nanoparticle concentration to $2 \%$ decreased the antibacterial activity; however, the authors did not give an explanation for this fact.

An advantage of YFN over all other nanoparticles considered above is the presence of remineralization activity apart from the antibacterial activity.

However, compared to composites based on YFN, the introduction of zinc(II) oxide composites into orthodontic acrylic resins improves both antimicrobial and mechanical properties of orthodontic appliances, such as flexural strength and Vickers hardness [88]. This makes them most appropriate for orthodontic dentistry applications.

It is worth noting that most of the publications considered in this section address the antimicrobial activity against only one or two types of microorganisms; meanwhile, the oral microflora is quite diverse.

\section{Dental Implantology and Dental Prosthetics}

Modification of the surface of dental implants with nanoparticles reduces the probability of post-implantation infection owing to their antimicrobial action.

\subsection{Materials Containing Silver Nanoparticles}

After dental implantation or prosthetics, an important task is to prevent C. albicans c and C. glabrata fungal infections in order to avoid repeated surgery because of infection. Silver NPs exhibit higher antimicrobial activity than antifungal drugs such as fluconazole, griseofulvin, itraconazole, and miconazole; therefore, silver nanoparticles are used to modify heat-curing and self-curing acrylic dental composites.

Since dental prostheses made of PMMA are actively colonized by fungi, De Matteis et al. [91] attempted to control fungal infection by adding Ag NPs/sodium citrate of $20 \mathrm{~nm}$ diameter to the PMMA-based Paladon 65 material. The negatively charged Ag NPs/sodium citrate particles decreased roughness, porosity, and hydrophobicity of the PMMA surface, thus decreasing adhesion and colonization of $C$. albicans on the polymer.

The metabolic activity of $C$. glabrata was studied in the presence of composites based on Lucitone 550 acrylic resin containing Ag NPs/sodium citrate [92]. It was found that 0.5 to 5 vol. \% nanoparticle concentrations in the composite resulted in the formation of aggregates. However, the authors noted that a decrease in the Ag NPs concentration to 0.05 vol. \% decreases the metabolic activity of C. glabrata biofilms by $43 \%$.

\subsection{Materials Containing Chitosan Nanoparticles}

In order to prevent complications of dental prosthetics such as stomatitis and chronic atrophic candidiasis, it was proposed to deposit a tissue acrylic conditioner containing $40 \mathrm{~nm}$ to $100 \mathrm{~nm}$ Cs NPs on the complete denture surface [93]. Samples containing $2.5 \mathrm{wt}$ \% to 10 wt. \% Cs NPs completely inhibited the growth of C. albicans fungi and S. mutans, $P$. aeruginosa, and E. faecalis bacteria after incubation for $24 \mathrm{~h}$. The inhibitory action of Cs NPs was attributed to the interaction of chitosan, which is a polycation, with anionic components of the cell walls of microorganisms [93].

\subsection{Materials Containing Nanodiamonds}

Fouda et al. [51] estimated the adhesion of C. albicans, the main causative agent of the denture stomatitis, to the cured Major Base 20 acrylic resin depending on the content of NDs (0.5-1.5 wt. \%). The lowest CFU count ( 290 per $\mu \mathrm{L}$ of the resin) was observed for $1 \%$ NDs. For the control group, this count was $\sim 1300$ per $\mu \mathrm{L}$ of the resin. In turn, the addition of $0.5 \mathrm{wt}$ \% NDs to the resin enhanced the mechanical properties of the composite and decreased the surface roughness [43]. The decrease in roughness deteriorated the 
microbial adhesion to the denture and improved the esthetic quality of the denture and patients' comfort.

Acrylic resins with quaternized nanodiamonds (below QNDs) can markedly decrease the number of viable $S$. mutans bacterial cells. After testing, a non-modified polymer disk was mainly covered with viable bacteria, while in case of QND-containing resins, both viable and dead cells were detected on the disk. Furthermore, the area of viable cells decreased with increasing QND concentration. When $1.0 \mathrm{wt}$. \% and $1.5 \mathrm{wt}$. \% QNDs was introduced into the resin, the number of viable bacteria on the disks decreased to $37.9 \%$ and 25.3\%, respectively. These QND-containing resins are intended for the manufacture of tooth dentures [94].

\subsection{Materials Containing Zinc(II) Oxide Nanoparticles}

The antifungal properties of tissue conditioners such as GC Soft-liner, based on plasticized polyether methacrylate and containing various amounts of $\mathrm{ZnO}$ NPs, were evaluated [95]. It is reported that air conditioners containing $15 \mathrm{wt}$. \% ZnO NPs reduced by an order of magnitude the number of $C$. albicans fungi cells compared with the control group after 7 and 14 days of observation. However, air conditioners containing 5 wt. $\%$ and $10 \mathrm{wt}$. \% ZnO NPs did not show a statistically significant reduction in the number of C. albicans compared to the control group. The authors explain this fact by the possible leaching of ZnO NPs due to the absence of bonds between nanoparticles and the polymer matrix of the air conditioner. In the future, the authors plan to investigate the cytotoxicity of the resulting materials.

\subsection{Materials Containing Titanium(IV) Oxide Nanoparticles}

In the work of Cascione et al. [96], to solve the problem of adhesion of microorganisms to the surface of dentures based on PMMA and the low strength of such dentures, two composites were developed and studied based on $\mathrm{PMMA}$ and $\mathrm{TiO}_{2} \mathrm{NPs}$, and the same polymer with HNTs.

Material properties were assessed in terms of physical parameters such as Young's modulus, roughness, and wettability, and the reduction in the concentration of the diploid fungus $C$. albicans was evaluated. Both types of material showed an improvement in these characteristics in comparison with unmodified composites. The improvement in properties correlated with the concentration of added nanoparticles. At the same time, the authors of [96] found that materials containing $\mathrm{TiO}_{2} \mathrm{NPs}$ had higher Young's modulus and, consequently, stiffness, in comparison with materials containing HNTs (Figure 4).

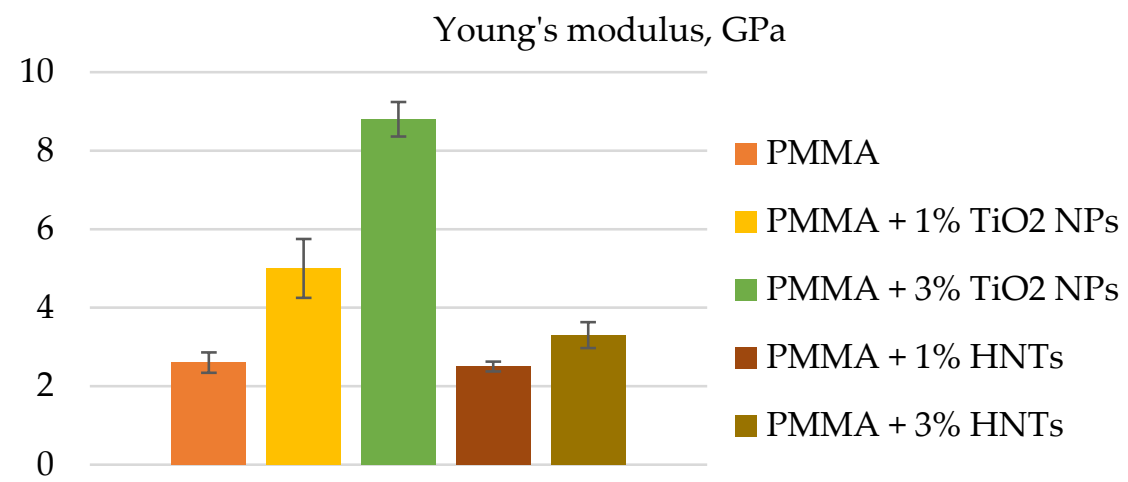

Figure 4. The mean value and its standard deviation of Young's modulus, evaluated for control (PMMA), PMMA + 1\% TiO 2 NPs, PMMA + 3\% TiO 2 NPs, PMMA + 1\% HNTs, and PMMA + 3\% HNTs, are represented. Reported results were considered statistically significant respect to control (PMMA) for a $p$-value $<0.005$. 
For C. albicans, it was found that composites containing HNTs reduced the rate of colo-

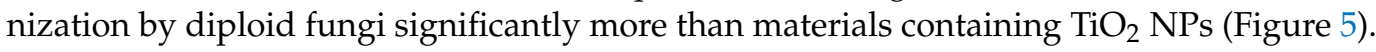
However, the authors did not explain this fact.

Percentage of colonized area, \%
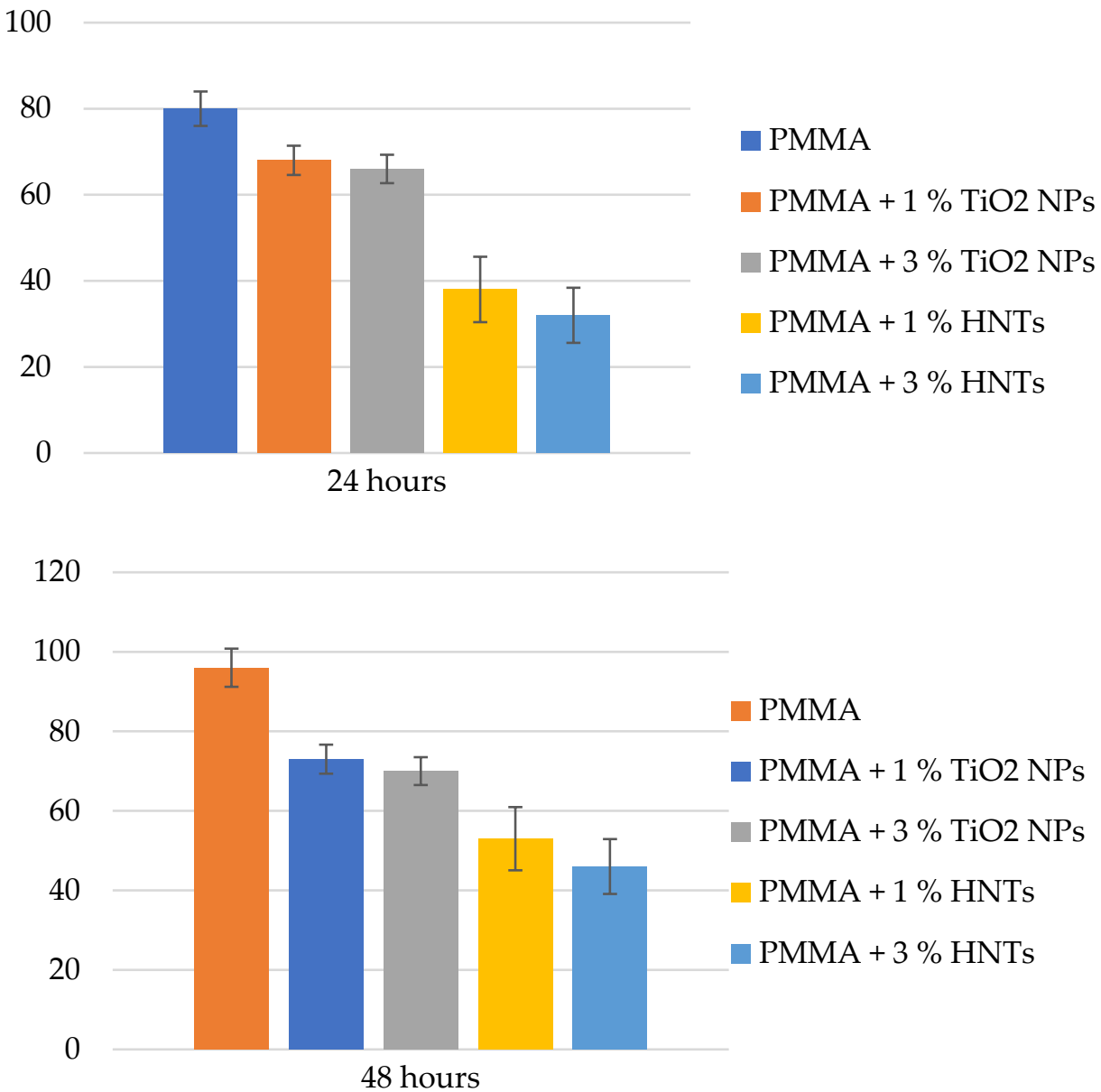

Figure 5. Histograms reporting the colonization assay measurements of C. albicans on (PMMA) and different PMMA-based substrates. The colonized area was expressed as a percentage rate representing the area covered by $C$. albicans in respect to the entire surface at two time points ( $24 \mathrm{~h}$ and $48 \mathrm{~h}$ ). Reported results were calculated as average \pm SD for three different areas of each sample, and the values were considered statistically significant in respect to control (PMMA at corresponding time point) for a $p$-value $<0.005$.

\subsection{Materials Containing Copper(II) Oxide Nanoparticles}

In a study of the antibiofilm activity of the self-cured acrylic-based GC Soft-liner containing $\mathrm{CuO}$ NPs in relation to the C. albicans biofilm, it was found that the material inhibits the growth of the C. albicans biofilm in a dose-dependent manner (in particular, up to $75 \%$ at a concentration of $\mathrm{CuO}$ NPs $500 \mu \mathrm{g} \mathrm{mL}^{-1}$ ) [61].

A comparison was also made of the antimicrobial activity of PMMA-based denture composites containing $\mathrm{CuO}$ NPs (2.5 wt. \% and 7.5 wt. \%) and $\mathrm{TiO}_{2} \mathrm{NPs}(2.5 \mathrm{wt} . \%$ and 7.5 wt. \%) against fungi of the genus Candida-C. albicans, C. dubliniensis- and bacteria of the genus Streptococcus (S. mutans, S. sobrinus, S. salivarius, S. sanguis) [97].

All samples had antimicrobial activity against $S$. salivarius, S. sanguis, and C. dubliniensis. However, only samples containing $2.5 \mathrm{wt}$. \% and $7.5 \mathrm{wt}$ \% CuO NPs were active against $S$. mutans bacteria. In relation to bacteria $S$. sobrinus, samples with $2.5 \mathrm{wt}$ \% and 7.5 wt. \% of $\mathrm{TiO}_{2}$ NPs and with 7.5 wt. \% of $\mathrm{CuO}$ NPs had activity, and in relation to fungi C. albicans, only samples with $7.5 \mathrm{wt}$. $\%$ of $\mathrm{TiO}_{2} \mathrm{NPs}$ showed activity. 
Unfortunately, the authors of this work studied composites with only two concentrations of $\mathrm{CuO}$ NPs and $\mathrm{TiO}_{2} \mathrm{NPs}$.

Summarizing the above, we can conclude that materials containing silver, chitosan, titanium(IV) oxide and copper(II) oxide nanoparticles, halloysite nanotubes, and nanodiamonds have activity against fungi of the genus Candida, the main pathogens in the field of dental implantology and dental prosthetics. Materials based on zinc(II) oxide nanoparticles are effective against $C$. albicans only if their content in the composite is high (more than 15 wt. \%).

\section{Maxillofacial Surgery}

The introduction of nanofillers into a polymer matrix for the manufacture of maxillofacial prostheses is aimed at improving the physicomechanical properties of prostheses and increasing the compressive strength, flexural strength, and microhardness of materials. However, some of them also possess a high antimicrobial activity, which is important as well.

\subsection{Materials Containing Titanium(IV) Oxide Nanoparticles}

A fundamental goal of maxillofacial prostheses is the restoration of the lost esthetic appearance of the upper and lower jaws. Silicone elastomers filled with $\mathrm{TiO}_{2} \mathrm{NPs}$ act as an ideal impression material for the elimination of maxillofacial defects owing to the antibacterial properties of $\mathrm{TiO}_{2} \mathrm{NPs}$ against $S$. aureus and E. coli. For example, Salih et al. [98] reported a 2.5-fold increase in the antibacterial activity of a material based on Versiltal RTV silicone elastomer and PMMA with the addition of $0.1 \mathrm{wt}$. $\% \mathrm{TiO}_{2} \mathrm{NPs}$.

\subsection{Materials Containing Bioactive Glass Nanoparticles}

Composites based on zein and silver-doped BGN were proposed for jaw bone tissue engineering. The antibacterial properties of the composites against E. coli and S. aureus were studied in vitro. The experiments were carried out [99] using porous zein/BGN and silver-doped BGN 3D scaffolds. It was noted that the scaffolds containing BGN without silver exhibited no antibacterial activity, unlike the scaffolds containing silver-doped BGN, as indicated by the absence of inhibition zones of bacterial growth. However, the authors did not report the diameters of inhibition zones, which is a considerable drawback of the study.

Over the past two years, there were almost no publications devoted to antimicrobial properties of nanomaterials for maxillofacial prostheses. The researchers' attention was focused on the cytotoxicity [100], physicomechanical properties [101,102], and osseointegration [103] because these materials should have a mechanical strength similar to bone tissue strength and should be nontoxic on contact with biological fluids and living tissues of the human body. Nevertheless, microorganisms can form biofilms on the surface of maxillofacial prostheses, which gives rise to purulent inflammatory processes; therefore, it would be appropriate to study the effect of nanoparticles on antimicrobial characteristics of materials used in this field of dentistry.

\section{Prospects for the Application of Dental Materials Containing Nanoparticles of Various Classes}

The application of polymeric nanomaterials in dentistry may increase the efficiency of treatment of diseases of hard dental, gingival, and periodontal tissues.

Materials containing silver nanoparticles show promise to be used in filling and restorative dental materials in dental therapy, adhesives and sealers in endodontics, acrylic resins for the manufacture of dentures, and in periodontal materials. The broad scope of applications of materials containing silver nanoparticles in dentistry is due to their lack of toxicity, anti-inflammatory action, and ability not only to endow dental materials with antibacterial and antifungal properties but also to improve their mechanical properties.

Zinc oxide nanocomposites can be used in dental therapy, periodontics, and orthodontics. 
However, the antibacterial activity of zinc oxide nanoparticles decreases with aging of dental materials [90]. In addition, zinc oxide nanoparticles of any size and concentration exhibit low antifungal activity.

Titanium dioxide nanocomposites are promising restorative materials and composites for the manufacture of orthodontic appliances and maxillofacial prostheses.

Magnesium oxide nanoparticles deteriorate the mechanical properties of filling materials [76]. They have low efficiency against bacteria, while their antifungal properties are unexplored.

Hydroxyapatite nanoparticles show antimicrobial activity only at high concentrations in dental material. Therefore, hydroxyapatite nanoparticles can be used as additives to filler materials in dental therapy only in combination with silver ions [104].

Zirconium dioxide nanoparticles can adversely affect the physical and esthetic properties of dentures, for example, by increasing surface roughness and decreasing the transparency of PMMA [105]. Therefore, zirconium dioxide nanoparticles are of no interest as dental prosthetics.

Bioactive glass nanoparticles can be used as fillers for polymeric orthodontic materials since, apart from their antibacterial effect, they increase the materials' hardness [36].

Materials filled with chitosan nanoparticles are less promising for dental therapy and endodontics than materials containing inorganic nanoparticles, e.g., zinc oxide nanoparticles, since they are less efficient against microorganisms. Furthermore, chitosan nanoparticles are cytotoxic to normal human dental pulp cells, substantially reducing their proliferation and viability [106].

Materials containing halloysite nanotubes are promising materials for the manufacture of partial and complete removable dentures in the field of dental prosthetics.

However, most studies of dental materials containing nanoparticles have been based on in vitro experiments, while in vivo studies allow working with multi-species biofilms and are considered more accurate than in vitro ones. Therefore, there is growing need of further experiments in vivo for implementation of these materials into clinical practice.

One of the problems that may limit the use and implementation of dental nanomaterials in clinical practice is their potential toxicity to patient tissues during prolonged exposure to the oral cavity. Toxicity is due to the leaching of nanosized fillers from the material and their effect on the cells of surrounding biological tissues. Toxicity and biocompatibility studies are of great importance for the clinical application of dental nanomaterials, especially in the field of dental implantology and dental prosthetics, since implants and prostheses come into contact with living tissues. However, it should be noted that the toxicity and biocompatibility of dental nanomaterials have not been studied in most of the considered works.

\section{Conclusions}

The presented literature review shows the prospects for the use of polymeric dental materials containing nanoparticles of various classes in such areas of dentistry as dental therapy, orthodontics, dental implantology, dental prosthetics, and maxillofacial surgery in terms of their antimicrobial activity. The innovations described in the review set a new vector of development in relation to restorative dental materials and composites, aimed at improving the quality of life of patients.

Researchers are continuously working on nanoparticle-filled dental materials capable of preserving the natural color of hard dental tissue without change over time, antimicrobial action, low cytotoxicity, high (compressive, tensile, and shear) strength, microhardness, impact strength, radiopacity, and color stability, and also high chemical stability. For example, composites filled with hybrid nanoparticles based on phosphazenes containing carboxyl groups [107,108] and methacrylic groups [109] are promising filler materials. 
Supplementary Materials: The following supporting information can be downloaded at: https:// www.mdpi.com/article/10.3390/polym14050864/s1, Table S1: Antimicrobial action of nanoparticles and their fields of application in dentistry; Table S2: Major dental pathogens; Table S3: Minimum inhibitory concentration (MIC); Table S4: Surface roughness values $\left(\mathrm{R}_{\mathrm{a}}\right)$.

Author Contributions: Conceptualization, E.C. and P.Y.; methodology, E.C.; validation, E.C., V.C., B.K., A.K., P.Y., Y.M.; writing-original draft preparation, P.Y.; writing-review and editing, E.C.; visualization, P.Y.; supervision, E.C.; funding acquisition, Y.M.; project administration, E.C. All authors have read and agreed to the published version of the manuscript.

Funding: The researchers received financial support from the Ministry of Science and Higher Education of the Russian Federation as part of the state task for the FSSM-2020-0004 project.

Institutional Review Board Statement: Not applicable.

Informed Consent Statement: Not applicable.

Data Availability Statement: Not applicable.

Conflicts of Interest: The authors declare no conflict of interest.

\begin{tabular}{|c|c|}
\hline Ag NPs & silver nanoparticles \\
\hline BGN & bioactive glass nanoparticles \\
\hline BHI & brain heart infusion broth \\
\hline CFU & colony-forming unit \\
\hline Cs NPs & chitosan nanoparticles \\
\hline $\mathrm{CuO}$ NPs & copper oxide nanoparticles \\
\hline DNA & deoxyribonucleic acid \\
\hline GIC & glass ionomer cement \\
\hline HNTs & halloysite nanotubes \\
\hline MDPC-23 & odontoblast-like cell line \\
\hline MIC & minimal inhibitory concentration \\
\hline $\mathrm{MgO}$ NPs & magnesium oxide nanoparticles \\
\hline $\mathrm{nCaF}_{2}$ & calcium fluoride nanoparticles \\
\hline L929 & mouse fibroblast cell line \\
\hline NCP & calcium phosphate nanoparticles \\
\hline NDs & nanodiamonds \\
\hline nHAps & hydroxyapatite nanoparticles \\
\hline PMMA & poly(methyl methacrylate) \\
\hline $\mathrm{TiO}_{2} \mathrm{NPs}$ & titanium(IV) oxide nanoparticles \\
\hline QND & quaternized nanodiamond \\
\hline YFN & yttrium fluoride nanoparticles \\
\hline $\mathrm{ZnO} \mathrm{NPs}$ & zinc oxide nanoparticles \\
\hline $\mathrm{ZrO}_{2} \mathrm{NPs}$ & zirconium(IV) oxide nanoparticles \\
\hline
\end{tabular}

\section{References}

1. Zhidkov, I.S.; Kurmaev, E.Z.; Cholakh, S.O.; Fazio, E.; D’Urso, L. XPS study of interactions between linear carbon chains and colloidal Au nanoparticles. Mendeleev Commun. 2020, 30, 285-287. [CrossRef]

2. Strutynska, N.; Livitska, O.; Prylutska, S.; Yumyna, Y.; Zelena, P.; Skivka, L.; Malyshenko, A.; Vovchenko, L.; Strelchuk, V.; Prylutskyy, Y.; et al. New nanostructured apatite-type $\left(\mathrm{Na}^{+}, \mathrm{Zn}^{2+}, \mathrm{CO}^{32-}\right)$-doped calcium phosphates: Preparation, mechanical properties and antibacterial activity. J. Mol. Struct. 2020, 1222, 128932. [CrossRef]

3. Owonubi, S.J.; Ateba, C.N.; Revaprasadu, N. Co-assembled ZnO-Fe ${ }_{2} \mathrm{O}_{3} x-\mathrm{CuOx}$ nano-oxide materials for antibacterial protection. Phosphorus Sulfur Silicon Relat. Elem. 2020, 195, 981-987. [CrossRef]

4. Aleksandrova, G.P.; Sapozhnikov, A.N.; Boymirzaev, A.S.; Sukhov, B.G.; Trofimov, B.A. Nanobiocomposites of Pharmacophoric Iron and Bismuth Oxides with Arabinogalactan Matrix. Russ. J. Gen. Chem. 2020, 90, 672-679. [CrossRef]

5. Mikhlin, Y.; Nasluzov, V.; Ivaneeva, A.; Vorobyev, S.; Likhatski, M.; Romanchenko, A.; Krylov, A.; Zharkov, S.; Meira, D.M. Formation, evolution and characteristics of copper sulfide nanoparticles in the reactions of aqueous cupric and sulfide ions. Mater. Chem. Phys. 2020, 255, 123600. [CrossRef] 
6. Kazaryan, S.A.; Starodubtsev, N.F. Study of the Optical and Luminescent Properties of Carbon Nanoparticles Using the Microphotoluminescence Method. Inorg. Mater. Appl. Res. 2020, 11, 243-256. [CrossRef]

7. Kuzub, L.I.; Guriev, L.L.; Khodos, I.I.; Badamshina, E.R. Influence of Precursor Concentration on the Formation of Silver Nanoparticles with Oligostyrylmonocarboxylate Ligands in ED-20 Epoxy Oligomer. Polym. Sci. Ser. B 2020, 62, $299-305$. [CrossRef]

8. Dahlan, A.S. Impact of Nanotechnology on High Performance Cement and Concrete. J. Mol. Struct. 2020, 1223, 128896. [CrossRef]

9. Hosny, N.M.; Sherif, Y.E. Novel synthesis and optical properties of $\mathrm{CaSb}_{2} \mathrm{O}_{6}$ nanoparticles via thermal decomposition of thioacetate precursor. Phosphorus Sulfur Silicon Relat. Elem. 2019, 195, 60-64. [CrossRef]

10. Vibhute, S.P.; Mhaldar, P.M.; Shejwal, R.V.; Pore, D.M. Magnetic Nanoparticles-Supported Palladium catalyzed Suzuki-Miyaura Cross Coupling. Tetrahedron Lett. 2020, 61, 151594. [CrossRef]

11. Harrison, A.; Zeevi, M.P.; Vasey, C.L.; Nguyen, M.D.; Tang, C. Accelerated Reaction Rates within Self-Assembled Polymer Nanoreactors with Tunable Hydrophobic Microenvironments. Polymers 2020, 12, 1774. [CrossRef]

12. Kim, H.-S.; Joo, S.-R.; Shin, U.S.; Kim, S.-H. Recyclable CNT-Chitosan nanohybrid film utilized in copper-catalyzed aerobic ipso-hydroxylation of arylboronic acids in aqueous media. Tetrahedron Lett. 2018, 59, 4597-4601. [CrossRef]

13. Korobov, I.I.; Kovalev, D.Y.; Vinokurov, A.A.; Nadkhina, S.E.; Kalinnikov, G.V.; Konovalikhin, S.V.; Khomenkob, N.Y.; Shilkin, S.P. Synthesis of Titanium Diboride Nanoparticles via the Reaction of TiCl4 with NaBH4 in NaCl-KCl Ionic Melt. Russ. J. Gen. Chem. 2020, 90, 924-926. [CrossRef]

14. Kazemi, H.; Adelkhani, H.; Didehban, K.; Kazazi, M.; Ajami, N. Electrophoretic as New Method for Deposition of Polyaniline Derivatives Nanostructure Coatings. Polym. Sci. Ser. B 2019, 61, 835-845. [CrossRef]

15. Shumyantseva, V.V.; Bulko, T.V.; Kuzikov, A.V.; Masamrekh, R.A.; Pergushov, D.V.; Schacher, F.H.; Sigolaeva, L.V. Electrochemical fingerprint of cytochrome c on a polymer/MWCNT nanocomposite electrode. Mendeleev Commun. 2020, 30, 299-301. [CrossRef]

16. Bhardwaj, R.; Jha, R. Trisodium citrate assisted morphology-controlled synthesis of nickel sulphide nanoparticles with enhanced cyclic stability as carbonaceous free electrode material. Mater. Chem. Phys. 2020, 255, 123581. [CrossRef]

17. Neskoromnaya, E.A.; Burakov, A.E.; Melezhik, A.V.; Babkin, A.V.; Burakova, I.V.; Kurnosov, D.A.; Tkachev, A.G. Synthesis and Evaluation of Adsorption Properties of Reduced Graphene Oxide Hydro- and Aerogels Modified by Iron Oxide Nanoparticles. Inorg. Mater. Appl. Res. 2020, 11, 467-475. [CrossRef]

18. Bapat, R.A.; Joshi, C.P.; Bapat, P.; Chaubal, T.V.; Pandurangappa, R.; Jnanendrappa, N.; Gorains, B.; Khurana, S.; Kesharwani, P. The use of nanoparticles as biomaterials in dentistry. Drug Discov. Today 2019, 24, 85-98. [CrossRef]

19. Kishen, A.S. Nanotechnology in Endodontics. Current and Potential Clinical Applications; Springer Science \& Business Media: Cham, Switzerland, 2015. [CrossRef]

20. Lorscheider, F.L.; Vimy, M.J.; Summers, A.O. Mercury exposure from "silver" tooth fillings: Emerging evidence questions a traditional dental paradigm. FASEB J. 1995, 9, 504-508. [CrossRef]

21. Chan, K.H.; Mai, Y.; Kim, H.; Tong, K.C.; Ng, D.; Hsiao, J. Resin composite filling. Materials 2010, 3, 1228-1243. [CrossRef]

22. Lohbauer, U. Dental glass ionomer cements as permanent filling materials?-Properties, limitations and future trends. Materials 2010, 3, 76-96. [CrossRef]

23. Qiu, W.; Zhou, Y.; Li, Z.; Huang, T.; Xiao, Y.; Cheng, L.; Peng, X.; Zhang, L.; Ren, B. Application of antibiotics/antimicrobial agents on dental caries. BioMed Res. Int. 2020, 2020, 5658212. [CrossRef] [PubMed]

24. Wang, Y.; Zhu, M.; Zhu, X.X. Functional fillers for dental resin composites. Acta Biomater. 2021, 122, 50-65. [CrossRef] [PubMed]

25. Barot, T.; Rawtani, D.; Kulkarni, P. Nanotechnology-based materials as emerging trends for dental applications. RAMS 2021, 60, 173-189. [CrossRef]

26. Fauzi, N.A.; Ireland, A.J.; Sherriff, M.; Bandara, H.M.H.N.; Su, B. Nitrogen doped titanium dioxide as an aesthetic antimicrobial filler in dental polymers. Dent. Mater. 2022, 38, 147-157. [CrossRef] [PubMed]

27. Yazdani, J.; Ahmadian, E.; Sharifi, S.; Shahi, S.; Dizaj, S.M. A short view on nanohydroxyapatite as coating of dental implants. Biomed. Pharmacother. 2018, 105, 553-557. [CrossRef]

28. Wang, Z.; Wang, X.; Wang, Y.; Zhu, Y.; Liu, X.; Zhou, Q. NanoZnO-modified titanium implants for enhanced antibacterial activity, osteogenesis and corrosion resistance. J. Nanobiotechnol. 2021, 19, 1-23. [CrossRef]

29. Imazato, S.; Kohno, T.; Tsuboi, R.; Thongthai, P.; Xu, H.H.; Kitagawa, H. Cutting-edge filler technologies to release bio-active components for restorative and preventive dentistry. Dent. Mater. J. 2020, 39, 69-79. [CrossRef]

30. Ferrando-Magraner, E.; Bellot-Arcís, C.; Paredes-Gallardo, V.; Almerich-Silla, M.; García-Sanz, V.; Fernández-Alonso, M.; MontielCompany, J.M. Antibacterial Properties of Nanoparticles in Dental Restorative Materials. A Systematic Review and Meta-Analysis. Medicina 2020, 56, 55. [CrossRef]

31. Rajeshwari, H.R.; Dhamecha, D.; Jagwani, S.; Rao, M.; Jadhav, K.; Shaikh, S.; Puzhankara, L.; Jalalpure, S. Local drug delivery systems in the management of periodontitis: A scientific review. J. Control Release 2019, 307, 393-409.

32. Ketabat, F.; Pundir, M.; Mohabatpour, F.; Lobanova, L.; Koutsopoulos, S.; Hadjiiski, L.; Chen, X.; Papagerakism, P. Controlled Drug Delivery Systems for Oral Cancer Treatment-Current Status and Future Perspectives. Pharmaceutics 2019, 11, 302. [CrossRef] [PubMed] 
33. Carrouel, F.; Viennot, S.; Ottolenghi, L.; Gaillard, C.; Bourgeois, D. Nanoparticles as Anti-Microbial, Anti-Inflammatory, and Remineralizing Agents in Oral Care Cosmetics: A Review of the Current Situation. Nanomaterials 2020, 10, 140. [CrossRef] [PubMed]

34. Kati, F.A. Effect of the incorporation of zinc oxide nanoparticles on the flexural strength of auto-polymerized acrylic resins. J. Oral. Res. 2019, 8, 37-41. [CrossRef]

35. Leitune, V.C.B.; Schiroky, P.R.; Genari, B.; Camassola, M.; Samuel, S.M.W.; Collares, F.M. Nanoneedle-like zinc oxide as a filler particle for an experimental adhesive resin. Indian J. Dent. Res. 2019, 30, 777. [CrossRef] [PubMed]

36. Nam, H.J.; Kim, Y.M.; Kwon, Y.H.; Yoo, K.H.; Yoon, S.Y.; Kim, I.R.; Park, B.S.; Kim, Y.I. Fluorinated Bioactive Glass Nanoparticles: Enamel Demineralization Prevention and Antibacterial Effect of Orthodontic Bonding Resin. Materials 2019, 12, 1813. [CrossRef]

37. Jasso-Ruiz, I.; Velazquez-Enriquez, U.; Scougall-Vilchis, R.J.; Lara-Carrillo, E.; Toral-Rizo, V.H.; López-Castañares, R.; MoralesLuckie, R.A. Synthesis and Characterization of Silver Nanoparticles on Orthodontic Brackets: A New Alternative in the Prevention of White Spots. Coatings 2019, 9, 480. [CrossRef]

38. Behnaz, M.; Dalaie, K.; Mirmohammadsadeghi, H.; Salehi, H.; Rakhshan, V.; Aslani, F. Shear bond strength and adhesive remnant index of orthodontic brackets bonded to enamel using adhesive systems mixed with $\mathrm{TiO}_{2}$ nanoparticles. Dental Press J. Orthod. 2018, 23, 43. [CrossRef] [PubMed]

39. Barandehfard, F.; Rad, M.K.; Hosseinnia, A.; Rashidi, A.; Tahriri, M.; Tayebi, L. The evaluation of the mechanical characteristics of the synthesized glass-ionomer cements (GICs): The effect of hydroxyapatite and fluorapatite nanoparticles and glass powders. $J$. Aust. Ceram. Soc. 2019, 55, 507-517. [CrossRef]

40. Hamid, N.; Telgi, R.L.; Tirth, A.; Tandon, V.; Chandra, S.; Chaturvedi, R.K. Titanium Dioxide Nanoparticles and Cetylpyridinium Chloride Enriched Glass-Ionomer Restorative Cement: A Comparative Study Assessing Compressive Strength and Antibacterial Activity. Int. J. Clin. Pediatr. Dent. 2019, 43, 42-45. [CrossRef]

41. Alobiedy, A.N.; Alhille, A.H.; Al-Hamaoy, A.R. Mechanical properties enhancement of conventional glass ionomer cement by adding zirconium oxide micro and nanoparticles. J. Eng. 2019, 25, 72-81. [CrossRef]

42. Raorane, D.V.; Chaughule, R.S.; Pednekar, S.R.; Lokur, A. Experimental synthesis of size-controlled $\mathrm{TiO}_{2}$ nanofillers and their possible use as composites in restorative dentistry. Saudi Dent. J. 2019, 31, 194-203. [CrossRef]

43. Al-Harbi, F.A.; Abdel-Halim, M.S.; Gad, M.M.; Fouda, S.M.; Baba, N.Z.; Al Rumaih, H.S.; Akhtar, S. Effect of nanodiamond addition on flexural strength, impact strength, and surface roughness of PMMA denture base. Int. J. Prosthodont. 2019, 28, 417-425. [CrossRef] [PubMed]

44. Ergun, G.; Sahin, Z.; Ataol, A.S. The effects of adding various ratios of zirconium oxide nanoparticles to poly(methylmethacrylate) on physical and mechanical properties. J. Oral Sci. 2018, 60, 304-315. [CrossRef]

45. Azzawi, Z.G.; Hamad, T.I.; Kadhim, S.A.; Naji, G.A.H. Osseointegration evaluation of laser-deposited titanium dioxide nanoparticles on commercially pure titanium dental implants. J. Mater. Sci. Mater. Med. 2018, 29, 96. [CrossRef] [PubMed]

46. Yaqoob, A.A.; Umar, K.; Ibrahim, M.N.M. Silver nanoparticles: Various methods of synthesis, size affecting factors and their potential applications-A review. Appl. Nanosci. 2020, 10, 1369-1378. [CrossRef]

47. Jadhav, K.; Dhamecha, D.; Dalvi, B.; Patil, M. Green Synthesis of Silver Nanoparticles Using Salacia chinensis: Characterization and its Antibacterial Activity. Part. Sci. Technol. 2015, 33, 445-455. [CrossRef]

48. Jadhav, K.; Dhamecha, D.; Bhattacharya, D.; Patil, M. Green and ecofriendly synthesis of silver nanoparticles: Characterization, biocompatibility studies and gel formulation for treatment of infections in burns. J. Photochem. Photobiol. B 2016, 155, 109-115. [CrossRef] [PubMed]

49. Lee, S.H.; Jun, B.H. Silver Nanoparticles: Synthesis and application for nanomedicine. Int. J. Mol. Sci. 2019, 20, 865. [CrossRef]

50. Baras, B.H.; Melo, M.A.S.; Sun, J.; Oates, T.W.; Weir, M.D.; Xie, X.; Bai, Y.; Xu, H.H.K. Novel endodontic sealer with dual strategies of dimethylaminohexadecyl methacrylate and nanoparticles of silver to inhibit root canal biofilms. Dent. Mater. 2019, 35, 1117-1129. [CrossRef]

51. Fouda, S.M.; Gad, M.M.; Ellakany, P.; Al-Thobity, A.M.; Al-Harbi, F.A.; Virtanen, J.I.; Raustia, A. The effect of nanodiamonds on Candida albicans adhesion and surface characteristics of PMMA denture base material-an in vitro study. J. Appl. Oral Sci. 2019, 27, e20180779. [CrossRef] [PubMed]

52. Florez, F.L.E.; Hiers, R.D.; Larson, P.; Johnson, M.; O’Rear, E.; Rondinone, A.J.; Khajotia, S.S. Antibacterial dental adhesive resins containing nitrogen-doped titanium dioxide nanoparticles. Mater. Sci. Eng. C 2018, 93, 931-943. [CrossRef] [PubMed]

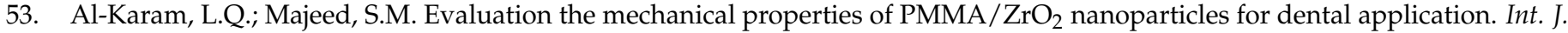
Pharm. Sci. 2019, 10, 2002-2007. [CrossRef]

54. Safaei, M.; Taran, M.; Imani, M.M.; Moradpoor, H.; Rezaei, F.; Jamshidy, L.; Rezaei, R. Application of Taguchi method in the optimization of synthesis of cellulose-MgO bionanocomposite as antibacterial agent. Polish J. Chem. Technol. 2019, 21, 116-122 [CrossRef]

55. Li, N.; Wu, G.; Yao, H.; Tang, R.; Gu, X.; Tu, C. Size effect of nano-hydroxyapatite on proliferation of odontoblast-like MDPC-23 cells. Dent. Mater. J. 2019, 38, 534-539. [CrossRef] [PubMed]

56. Salaie, R.N.; Besinis, A.; Le, H.; Tredwin, C.; Handy, R.D. The biocompatibility of silver and nanohydroxyapatite coatings on titanium dental implants with human primary osteoblast cells. Mater Sci. Eng. C 2020, 107, 110210. [CrossRef]

57. Bae, J.; Son, W.S.; Yoo, K.H.; Yoon, S.Y.; Bae, M.K.; Lee, D.J.; Ko, C.C.; Choi, Y.K.; Kim, Y.I. Effects of Poly (Amidoamine) Dendrimer-Coated Mesoporous Bioactive Glass Nanoparticles on Dentin Remineralization. J. Nanomater. 2019, 9, 591. [CrossRef] 
58. Asiry, M.A.; Alshahrani, I.; Alqahtani, N.D.; Durgesh, B.H. Efficacy of yttrium (III) fluoride nanoparticles in orthodontic bonding. J. Nanosci. Nanotechnol. 2019, 19, 1105-1110. [CrossRef]

59. Mitwalli, H.; Balhaddad, A.A.; AlSahafi, R.; Oates, T.W.; Melo, M.A.S.; Xu, H.H.; Weir, M.D. Novel CaF 2 nanocomposites with antibacterial function and fluoride and calcium ion release to inhibit oral biofilm and protect teeth. J. Funct. Biomater. 2020, 11, 56. [CrossRef]

60. Al-Qarni, F.D.; Tay, F.; Weir, M.D.; Melo, M.A.; Sun, J.; Oates, T.W.; Xie, X.; Xu, H.H. Protein-repelling adhesive resin containing calcium phosphate nanoparticles with repeated ion-recharge and re-releases. J. Dent. 2018, 78, 91-99. [CrossRef]

61. Ansarifard, E.; Zareshahrabadi, Z.; Sarafraz, N.; Zomorodian, K. Evaluation of Antimicrobial and Antibiofilm Activities of Copper Oxide Nanoparticles within Soft Denture Liners against Oral Pathogens. Bioinorg. Chem. Appl. 2021, 2021, 9939275. [CrossRef]

62. Zegan, G.; Toma, V.; Cernei, E.R.; Anistoroaei, D.; Carausu, E.M.; Moscu, M. Study on Antibiotic Loaded Nanoparticles for Oral Infection Treatment. Rev. Chim. 2019, 70, 1712-1714. [CrossRef]

63. Zegan, G.; Anistoroaei, D.; Carausu, E.M.; Cernei, E.R.; Golovcencu, L. Amoxicilin and Clavulanic Acid Intercaled Nanostructures for Dentistry Uses. Mater. Plast. 2019, 56, 396. [CrossRef]

64. Delan, W.K.; Zakaria, M.; Elsaadany, B.; ElMeshad, A.N.; Mamdouh, W.; Fares, A.R. Formulation of simvastatin chitosan nanoparticles for controlled delivery in bone regeneration: Optimization using Box-Behnken design, stability and in vivo study. Int. J. Pharm. 2020, 577, 119038. [CrossRef] [PubMed]

65. Nair, B.S.; Surendra Kumar, G.P.; Mithra, A.; Rao, S.; Murthy, T. To evaluate and compare the mechanical properties and wetting ability of heat polymerized polymethyl methacrylate resin after reinforcement with halloysite nanotubes and Titania nanoparticles. Int. J. Appl. Dent. Sci. 2021, 7, 374-379. [CrossRef]

66. Porenczuk, A.; Grzeczkowicz, A.; Maciejewska, I.; Gołaś, M.; Piskorska, K.; Kolenda, A.; Gozdowski, D.; Kopeć-Swoboda, E.; Granicka, L.; Olczak-Kowalczyk, D. An initial evaluation of cytotoxicity, genotoxicity and antibacterial effectiveness of a disinfection liquid containing silver nanoparticles alone and combined with a glass-ionomer cement and dentin bonding systems. Adv. Clin. Exp. Med. 2019, 28, 75-83. [CrossRef]

67. Oh, G.J.; Kim, J.W.; Ji, M.K.; Yim, E.K.; Vu, V.T.; Kang, B.M.; Park, S.W.; Yang, H.S.; Moon, B.K.; Lee, K.K.; et al. Antibacterial Activity and Fibroblast Cell Viability of Zirconia Coated with Glass Ceramic Containing Ag and NaF Nanoparticles. J. Nanosci. Nanotechnol. 2019, 19, 1035-1037. [CrossRef]

68. Mohammed, H.F.; Riad, M.I. The effect of silver nanoparticles incorporation in the self-etch adhesive system on its antibacterial activity and degree of conversion: An in-vitro study. F1000Research 2019, 8, 244. [CrossRef]

69. Santoso, J.; Purbiati, M. Antibacterial activity of silver nanoparticles on fixed retainer adhesive toward Treponema denticola. Int. J. Pharm. 2019, 11, 198-200. [CrossRef]

70. Prasetyo, B.C.; Sugiharti, R.J.; Mahendra, I.; Halimah, I.; Widyasar, E.M.; Rusminah, N.; Mustika, I. Evaluation of Silver Nanoparticles Addition in Periodontal Dressing for Wound Tissue Healing by 99mTc-ciprofloxacin. J. Young Pharm. 2019, 11, 17-20. [CrossRef]

71. Craciunescu, O.; Seciu, A.M.; Manoiu, V.S.; Trif, M.; Moisei, M.; Nicu, A.I.; Zarnescu, O. Biosynthesis of silver nanoparticles in collagen gel improves their medical use in periodontitis treatment. Particul. Sci. Technol. 2019, 37, 757-763. [CrossRef]

72. Angel Villegas, N.; Silvero Compagnucci, M.J.; Sainz Ajá, M.; Rocca, D.M.; Becerra, M.C.; Fabián Molina, G.; Palma, S.D. Novel Antibacterial Resin-Based Filling Material Containing Nanoparticles for the Potential One-Step Treatment of Caries. J. Healthc. Eng. 2019, 2019, 6367919. [CrossRef] [PubMed]

73. Mirhosseini, F.; Amiri, M.; Daneshkazemi, A.; Zandi, H.; Javadi, Z.S. Antimicrobial Effect of Different Sizes of Nano Zinc Oxide on Oral Microorganisms. Front. Dent. 2019, 16, 105. [CrossRef] [PubMed]

74. Wang, J.; Du, L.; Fu, Y.; Jiang, P.; Wang, X. ZnO nanoparticles inhibit the activity of Porphyromonas gingivalis and Actinomyces naeslundii and promote the mineralization of the cementum. BMC Oral Health 2019, 19, 84. [CrossRef] [PubMed]

75. Javed, R.; Rais, F.; Fatima, H.; ul Haq, I.; Kaleem, M.; Naz, S.S.; Ao, Q. Chitosan encapsulated ZnO nanocomposites: Fabrication, characterization, and functionalization of bio-dental approaches. Mater. Sci. Eng. C 2020, 116, 111184. [CrossRef] [PubMed]

76. Dias, H.B.; Bernardi, M.I.B.; Bauab, T.M.; Hernandes, A.C.; de Souza Rastelli, A.N. Titanium dioxide and modified titanium dioxide by silver nanoparticles as an anti- biofilm filler content for composite resins. Dent. Mater. J. 2019, 35, 36-46. [CrossRef]

77. Noori, A.J.; Kareem, F.A. Setting time, mechanical and adhesive properties of magnesium oxide nanoparticles modified glassionomer cement. J. Mater. Res. Technol. 2020, 9, 1809-1818. [CrossRef]

78. Noori, A.J.; Kareem, F.A. The effect of magnesium oxide nanoparticles on the antibacterial and antibiofilm properties of glassionomer cement. Heliyon 2019, 5, e02568. [CrossRef]

79. Jardim, R.N.; Rocha, A.A.; Rossi, A.M.; de Almeida Neves, A.; Portela, M.B.; Lopes, R.T.; dos Santos, T.M.P.; Xing, Y.; da Silva, E.M. Fabrication and characterization of remineralizing dental composites containing hydroxyapatite nanoparticles. J. Mech. Behav. Biomed. Mater. 2020, 109, 103817. [CrossRef]

80. Al-Bakhash, J.A.B.; Shafiei, F.; Pourhajibagher, M.; Shekofteh, K.; Hashemian, A.; Behroozibakhsh, M. The antibacterial activity of an epoxy resin-based dental sealer containing bioactive glass, hydroxyapatite, and fluorohydroxyapatite nanoparticles against Enterococcus faecalis and Streptococcus mitis. Nanomed. J. 2020, 7, 13-20. [CrossRef]

81. Abdelrehim, M.M.; Mohy El Din, M.H.; El-Shabrawy, S.M.; Fahmy, A.E.; Abdelhamid, S.M.; Ramadan, H.S. Synthesis and characterization of metallic and polymeric nanoparticles and their effect on the antibacterial properties of microhybrid composite resin. Alex. Dent. J. 2019, 44, 39-45. [CrossRef] 
82. Jowkar, Z.; Jowkar, M.; Shafiei, F. Mechanical and dentin bond strength properties of the nanosilver enriched glass ionomer cement. J. Clin. Exp. Dent. 2019, 11, 275-281. [CrossRef] [PubMed]

83. Bhadila, G.; Wang, X.; Zhou, W.; Menon, D.; Melo, M.A.S.; Montaner, S.; Sun, J.; Xu, H.H. Novel low-shrinkage-stress nanocomposite with remineralization and antibacterial abilities to protect marginal enamel under biofilm. J. Dent. $2020,99,103406$. [CrossRef] [PubMed]

84. Lee, S.J.; Heo, M.; Lee, D.; Han, S.; Moon, J.-H.; Lim, H.-N.; Kwon, I.K. Preparation and characterization of antibacterial orthodontic resin containing silver nanoparticles. Appl. Surf. Sci. 2018, 432, 317-323. [CrossRef]

85. Soans, C.; Jenitta, E.P.; Murali, P.S.; Shetty, A.V.; Ravi, M.S.; Nayak, U.S. Evaluation of Antimicrobial Properties of Orthodontic Adhesive Mixed with Silver Nanoparticles: An in Vitro Study. Indian J. Public Health Res. Dev. 2019, 10, 32-38. [CrossRef]

86. Mirhashemi, A.; Bahador, A.; Sodagar, A.; Pourhajibagher, M.; Amiri, A.; Gholamrezayi, E. Evaluation of antimicrobial properties of nano-silver particles used in orthodontics fixed retainer composites: An experimental in-vitro study. J. Dent. Res. Dent. Clin. Dent. Proscpects. 2021, 15, 87-93. [CrossRef]

87. Hailan, S.Y.; Al-Khatieeb, M.M. Antimicrobial efficacy of silver, zinc oxide, and titanium dioxide nanoparticles incorporated in orthodontic bonding agent. J. Baghdad Coll. Dent. 2019, 31, 10-16. [CrossRef]

88. Mangal, U.; Kim, J.Y.; Seo, J.Y.; Kwon, J.S.; Choi, S.H. Novel Poly (Methyl Methacrylate) Containing Nanodiamond to Improve the Mechanical Properties and Fungal Resistance. Materials 2019, 12, 3438. [CrossRef]

89. Mangal, U.; Min, Y.J.; Seo, J.Y.; Kim, D.E.; Cha, J.Y.; Lee, K.J.; Kwon, J.-S.; Choi, S.H. Changes in tribological and antibacterial properties of poly (methyl methacrylate)-based 3D-printed intra-oral appliances by incorporating nanodiamonds. J. Mech. Behav. Biomed. Mater. 2020, 110, 103992. [CrossRef]

90. Pourhajibagher, M.; Vaziri, A.S.; Takzaree, N.; Ghorbanzadeh, R. Physico-mechanical and antimicrobial properties of an orthodontic adhesive containing cationic curcumin doped zinc oxide nanoparticles subjected to photodynamic therapy. Photodiagnosis Photodyn. Ther. 2019, 25, 239-246. [CrossRef]

91. De Matteis, V.; Cascione, M.; Toma, C.C.; Albanese, G.; De Giorgi, M.L.; Corsalini, M.; Rinaldi, R. Silver Nanoparticles Addition in Poly (Methyl Methacrylate) Dental Matrix: Topographic and Antimycotic Studies. Int. J. Mol. 2019, 20, 4691. [CrossRef]

92. De Souza Neto, F.N.; Sala, R.L.; Fernandes, R.A.; Xavier, T.P.O.; Cruz, S.A.; Paranhos, C.M.; Monteiro, D.R.; Barboss, D.B.; Delbem, A.C.B.; de Camargo, E.R. Effect of synthetic colloidal nanoparticles in acrylic resin of dental use. Eur. Polym. J. $2019,112,531-538$. [CrossRef]

93. Mousavi, S.A.; Ghotaslou, R.; Kordi, S.; Khoramdel, A.; Aeenfar, A.; Kahjough, S.T.; Akbarzadeh, A. Antibacterial and antifungal effects of chitosan nanoparticles on tissue conditioners of complete dentures. Int. J. Biol. Macromol. 2018, 118, 881-885. [CrossRef] [PubMed]

94. Zhang, Y.; Wang, X.; Li, Q.; Xiao, Y.; Li, P.; Wang, L.; Ye, Z.; Xing, X. Novel resin-based dental material with anti-biofilm activity and improved mechanical property by incorporating hydrophilic cationic copolymer functionalized nanodiamond. J. Mater. Sci. Mater. Med. 2018, 29, 162. [CrossRef]

95. Homsiang, W.; Kamonkhantikul, K.; Arksornnukit, M.; Takahashi, H. Effect of zinc oxide nanoparticles incorporated into tissue conditioner on antifungal, physical, and mechanical properties. Dent, Mater. J. 2021, 40, 481-486. [CrossRef] [PubMed]

96. Cascione, M.; De Matteis, V.; Pellegrino, P.; Albanese, G.; De Giorgi, M.L.; Paladini, F.; Corsalini, M.; Rinaldi, R. Improvement of PMMA Dental Matrix Performance by Addition of Titanium Dioxide Nanoparticles and Clay Nanotubes. Nanomaterials 2021, 11, 2027. [CrossRef]

97. Giti, R.; Zomorodian, K.; Firouzmandi, M.; Zareshahrabadi, Z.; Rahmannasab, S. Antimicrobial Activity of Thermocycled Polymethyl Methacrylate Resin Reinforced with Titanium Dioxide and Copper Oxide Nanoparticles. Int. J. Dent. 2021, 2021, 6690806. [CrossRef]

98. Salih, S.I.; Oleiwi, J.K.; Ali, H.M. Development the Physical Properties of Polymeric Blend (SR/PMMA) by Adding various Types of Nanoparticles, Used for Maxillofacial Prosthesis Applications. J. Eng. Technol. 2019, 37, 120-127. [CrossRef]

99. El-Rashidy, A.A.; Waly, G.; Gad, A.; Roether, J.A.; Hum, J.; Yang, Y.; Detsch, R.; Hashem, A.A.; Sami, I.; Goldmann, W.H.; et al. Antibacterial activity and biocompatibility of zein scaffolds containing silver-doped bioactive glass. Biomed. Mater. 2018, 13, 065006. [CrossRef]

100. Tukmachi, M.S.; Safi, I.N.; Ali, M.M.M. Evaluation of mechanical properties and cytotoxicity of maxillofacial silicone material after incorporation of zirconia nanopowder. Mater. Today Proc. 2021, 42, 2209-2217. [CrossRef]

101. Shakir, D.A.; Abdul-Ameer, F.M. Effect of nano-titanium oxide addition on some mechanical properties of silicone elastomers for maxillofacial prostheses. J. Taibah Univ. Medical. Sci. 2018, 13, 281-290. [CrossRef]

102. Abdul-Ameer, F.M. Impact of a mixture of nanofiller and intrinsic pigment on tear strength and hardness of two types of maxillofacial silicone elastomers. J. Dent. Res. J. 2020, 17, 251. [CrossRef]

103. Ibrahim, M.; Xue, Y.; Ostermann, M.; Sauter, A.; Steinmueller-Nethl, D.; Schweeberg, S.; Krueger, A.; Cimpan, M.R.; Mustafa, K. In vitro cytotoxicity assessment of nanodiamond particles and their osteogenic potential. J. Biomed. Mater. Res. A 2018, 106, 1697-1707. [CrossRef] [PubMed]

104. Erdem, U.; Dogan, M.; Metin, A.U.; Baglar, S.; Turkoz, M.B.; Turk, M.; Nezir, S. Hydroxyapatite-based nanoparticles as a coating material for the dentine surface: An antibacterial and toxicological effect. Ceram. Int. 2020, 46, 270-280. [CrossRef] 
105. Gad, M.M.; Rahoma, A.; Abualsaud, R.; Al-Thobity, A.M.; Akhtar, S.; Helal, M.A.; Al-Harbi, F.A. Impact of different surface treatments and repair material reinforcement on the flexural strength of repaired PMMA denture base material. Dent. Mater. J. 2020, 39, 471-482. [CrossRef] [PubMed]

106. Alhomrany, R.; Zhang, C.; Chou, L. Cytotoxic effect of chitosan nanoparticles on normal human dental pulp cells. Nanosci. Nanotechnol. 2019, 3, 1. [CrossRef]

107. Chistyakov, E.; Kolpinskaya, N.; Posokhova, V.; Chuev, V. Dental Composition Modified with Aryloxyphosphazene Containing Carboxyl Groups. Polymers 2020, 12, 1176. [CrossRef]

108. Chistyakov, E.M.; Panfilova, D.V.; Kireev, V.V. Carboxyl derivatives of phosphazenes. Russ. J. Gen. Chem. 2017, 87, 997-1006. [CrossRef]

109. Kireev, V.V.; Chistyakov, E.M.; Filatov, S.N.; Tupikov, A.; Panfilova, D.V.; Chetverikova, A.I. Polymeric dental composites modified with carboxy phosphazene methacrylates. Russ. J. Appl. Chem. 2015, 88, 866-870. [CrossRef] 